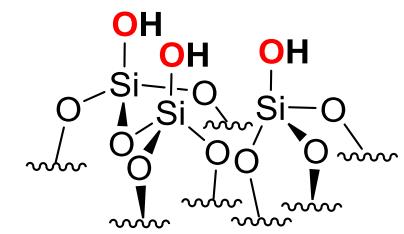

Gas-phase synthesis of reactive $\mathrm{Zn}$ sites on oxide supports

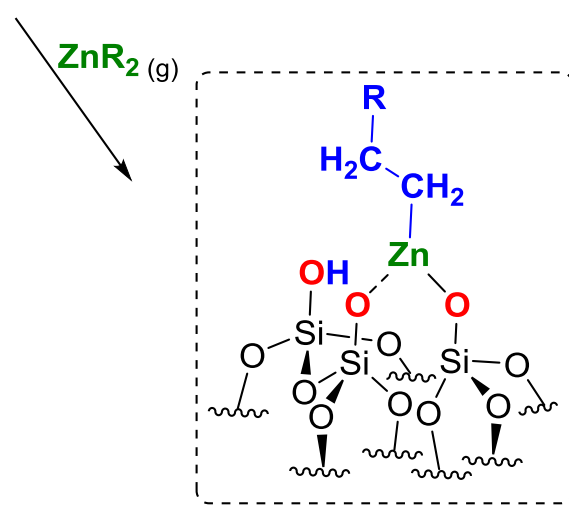

\title{
oxide supports
}

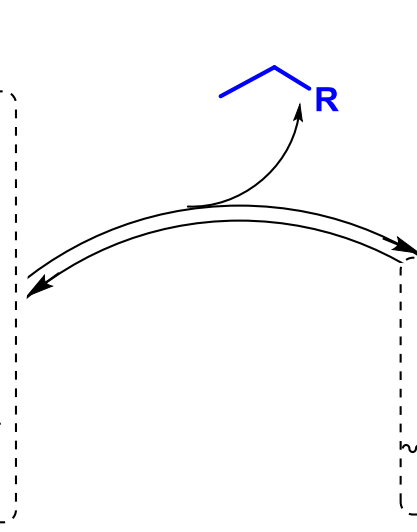

Supported Organo$\mathrm{Zn}$ (II) sites
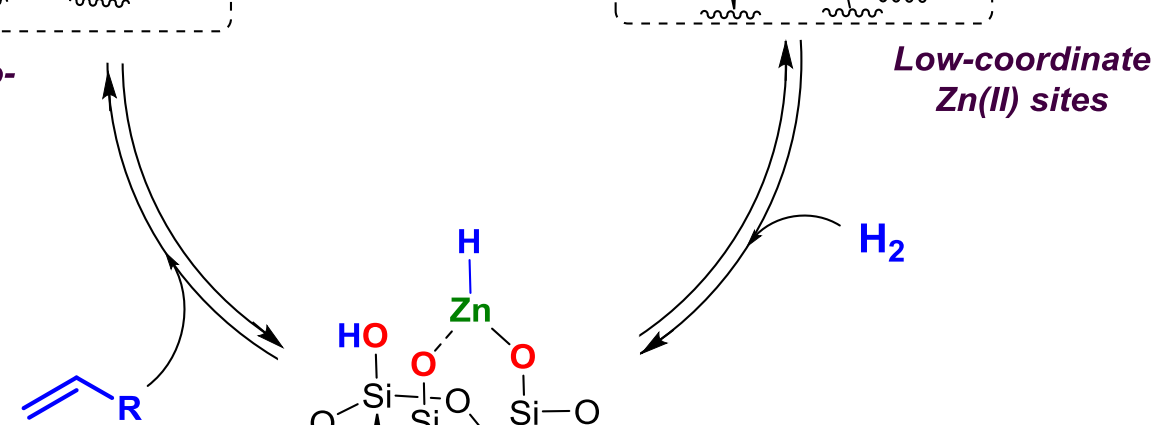


\title{
Single-Site Zinc on Silica Catalysts for Propylene Hydrogenation and Propane Dehydrogenation. Synthesis and Reactivity Evaluation Using An Integrated Atomic Layer Deposition-Catalysis Instrument
}

\author{
Jeffrey Camacho-Bunquin, ${ }^{1}$ Payoli Aich, ${ }^{1,2}$ Magali Ferrandon, ${ }^{1}$ Andrew "Bean" Getsoian, ${ }^{1}$ Ujjal \\ Das, ${ }^{1}$ Fulya Dogan, ${ }^{1}$ Larry A. Curtiss, ${ }^{1}$ Jeffrey T. Miller ${ }^{1,3}$ Christopher L. Marshall, ${ }^{1}$ Adam S. \\ Hock ${ }^{1,4} *$ and Peter C. Stair ${ }^{1,5}$
}

Keywords: hydrogenation, dehydrogenation, atomic layer deposition, zinc

\section{Abstract}

Alkyl-zinc and zinc oxide-type sites were synthesized via atomic layer deposition on highsurface-area silica using an integrated atomic layer deposition-catalysis instrument (I-ALDCAT). One-cycle ALD experiments using diethylzinc (DEZ) afforded $\mathrm{Zn} / \mathrm{SiO}_{2}$ systems that provided key insights into the reactivity and stability of $\mathrm{Zn}$ sites as a function of dispersion at the submonolayer level. The I-ALD-CAT tool design allowed for systematic comparison of the reactivity of different grafted zinc sites. Open-shell 16-electron, tricoordinate ethyl zinc-silica sites exhibit higher activity in propane hydrogenation-dehydrogenation compared to 18-electron, tetracoordinate zinc oxide-type centers. Silica surface saturation with $\mathrm{Zn}$ (II) sites ( $75 \%$ of a monolayer) results in facile zinc agglomeration and catalyst deactivation under reaction conditions. Reduced DEZ dosing coupled with thermal substrate pretreatment techniques (e.g., dehydration under vacuum) resulted in increased $\mathrm{Zn}$ dispersion and produced $\mathrm{Zn} / \mathrm{SiO}_{2}$ catalysts with improved activity and stability under propylene hydrogenation $\left(200^{\circ} \mathrm{C}\right)$ and propane dehydrogenation $\left(550^{\circ} \mathrm{C}\right)$ conditions.

\section{Introduction}

Single-site heterogeneous catalysis remains a rapidly growing area due to its potential to combine the tunability of molecular catalysts with the stability of heterogeneous materials under a range of process conditions (e.g., temperature, pressure, solvent). ${ }^{1,2}$ Systematic investigation of 
active site formation during synthesis and the transformations these species and reactive intermediates undergo during catalysis can harness key structural and mechanistic insights that are essential for the purposeful design of robust single-site catalysts with improved efficiency. However, systematic study of the transformations that these isolated sites undergo remains challenging due to the limitations of the synthesis procedures (e.g., formation of a distribution of sites), and the difficulty in handling sensitive catalytic species and intermediates from synthesis to the reactivity testing stage. Ideally, strategies integrating high-precision active site synthesis methods with immediate catalyst performance testing could allow for the systematic investigation of the catalytic properties of these supported sites without material decomposition from air- or moisture exposure.

In order to prepare single-site catalysts that are uniform-in-function, they must be synthesized using atomic-level control. ${ }^{3,4}$ Recent advances in synthesis techniques have produced catalytic materials with much improved activity, selectivity and stability. ${ }^{5-9}$ One thing all of these synthesis methods (e.g., impregnation, ion-exchange, precipitation, organometallic grafting) still lack in many cases is control of the structure, producing materials with a distribution of active sites, which in turn impacts performance. In principle, Atomic Layer Deposition (ALD) is a high-precision grafting technique that can synthesize a variety of supported catalytic sites (e.g., single atoms or clusters) at the atomic/monolayer level. ${ }^{3,10-11}$ ALD is a vapor-phase grafting method that relies on a stoichiometric and thus self-limiting reaction of chemical precursors with substrate surface functionalities. ${ }^{5-12}$ The self-limiting nature of the ALD process presents a number of synthetic advantages that include (1) uniform active site dispersion, (2) high conformity to surface features which, in certain cases, allows for maximum utilization of the support surface area, and (3) high level of reproducibility. ${ }^{3}$ 
Although ALD as a catalyst synthesis tool has been applied mainly for the controlled synthesis of supported bulk - nanoscale in size - structures such as metal particles, ${ }^{13}$ films, ${ }^{14}$ alloys ${ }^{15}$ and core-shell nanoparticles, ${ }^{16}$ it comprises an ideal strategy for accessing supported single-site catalysts since the initial nucleation of sites during ALD should consist of isolated sites. So far, only a few reports of ALD for single-atom catalysts have appeared. ${ }^{17}$ Hence, improved understanding of synthesis mechanisms and optimization of key factors for the design of effective ALD synthesis methods to access single sites is warranted.

Our group recently reported the synthesis of isolated, low-coordinate $\mathrm{Zn}$ (II) sites on silica via strong electrostatic adsorption. These sites were shown active toward propylene hydrogenation $\left(200{ }^{\circ} \mathrm{C}\right)$ and selective propane dehydrogenation $\left(550{ }^{\circ} \mathrm{C}\right)$. Computational studies revealed the involvement of a tricoordinate $\mathrm{Zn}$ (II) sites and an alkyl-zinc intermediate in the catalytic cycle (Fig 1). However, systematic comparison of the intrinsic reactivity of these intermediates remains challenging due to difficulties in the synthesis, and the inherent instability of the species on oxide supports.

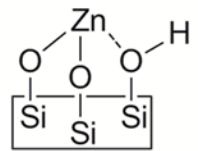

(a)

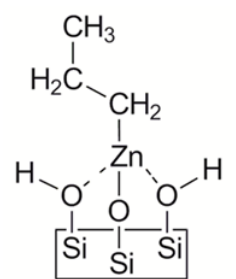

(b)

Figure 1. Proposed reactive intermediates for a previously reported single-site $\mathrm{Zn}(\mathrm{II}) / \mathrm{SiO}_{2}$ catalyst for propylene hydrogenation and propane dehydrogenation: (a) three-coordinate $\mathrm{Zn}$ (II) site and (b) alkyl-zinc species.

In this paper, we report the use of an Integrated Atomic Layer Deposition-Catalysis (IALD-CAT, Figure 2) ${ }^{18}$ synthesis and catalyst reaction testing tool for the synthesis of isolated alkyl-zinc and zinc oxide-type sites via one-cycle ALD methods and immediate in situ 
evaluation of the reactivity of these sites at the atomic-scale/submonolayer level under propylene hydrogenation and propane dehydrogenation conditions. ${ }^{18}$ The I-ALD-CAT tool - the first of its kind - has the capability of (1) ALD synthesis on a support loaded into a plug-flow reactor, a design element that allows for (2) immediate in situ catalyst performance evaluation under plugflow conditions without material exposure to air or moisture (Figure 2).

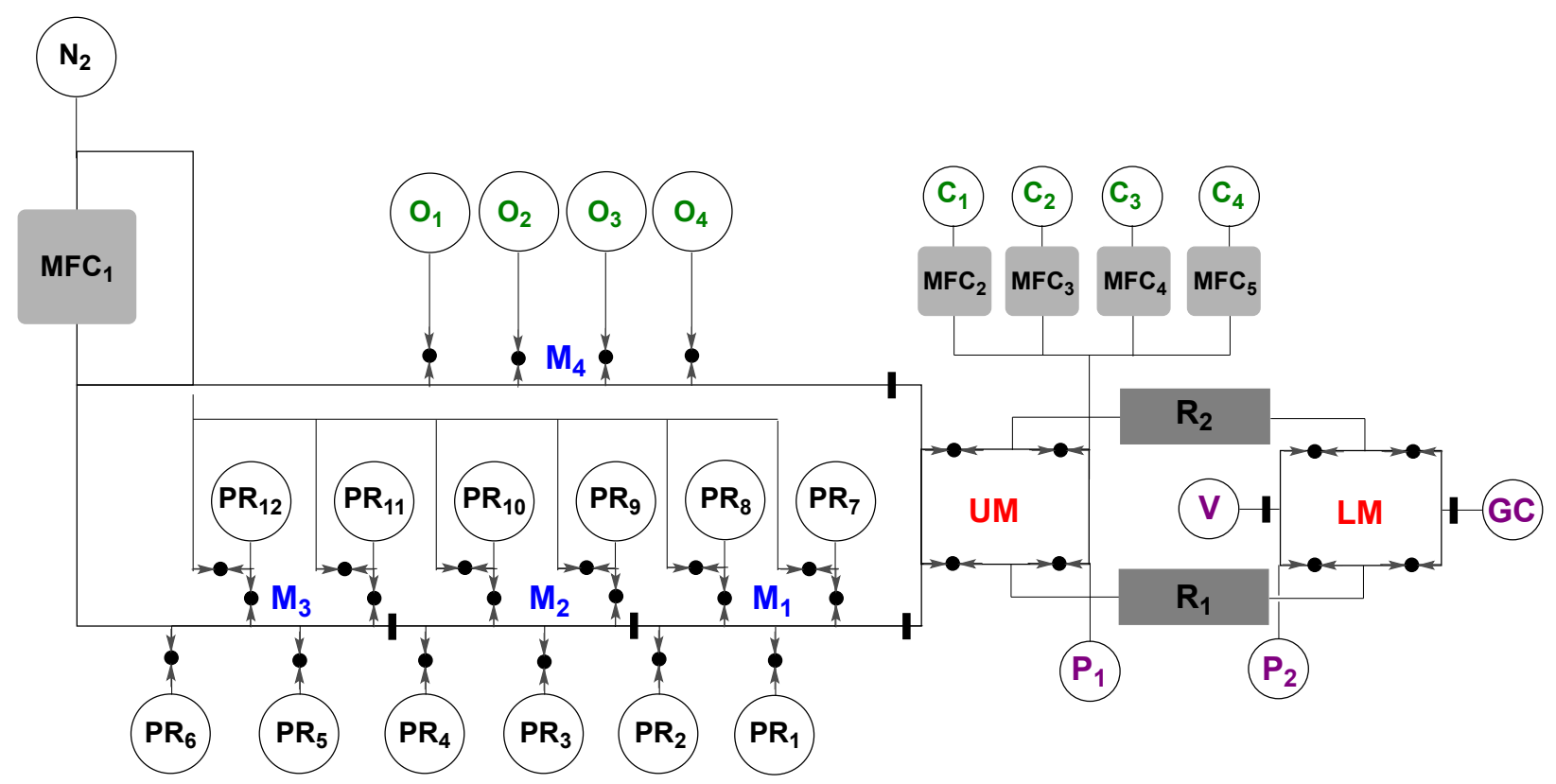

Figure 2. Schematic diagram for the I-ALD-CAT tool. Lower left: Metal precursors $\left(\mathrm{PR}_{1}-\right.$ $\left.\mathrm{PR}_{12}\right)$. Upper left: Oxidizing/reducing reagents $\left(\mathrm{O}_{1}-\mathrm{O}_{4}\right)$. Upper right: Catalysis reagents $\left(\mathrm{C}_{1}-\mathrm{C}_{4}\right)$. Middle right: Plug-flow reactors $\left(\mathrm{R}_{1}, \mathrm{R}_{2}\right)$. Middle far-right: Product manifold (LM). The I-ALDCAT has the capability of providing gaseous reagents comprised of 12 different ALD precursors, 4 oxidizing or reducing agents, and 4 catalytic reaction feeds to the two plug-flow reactors. The reactor is able to immediately test these single site catalysts (or any newly synthesized materials) on a wide range of reactions and process conditions. Volatile products of the ALD synthesis and catalytic reactions can be analyzed by both GC and mass spectrometry. ${ }^{18}$

The approach presented in this report provides key insights into the mechanism of zinc grafting on hydroxylated supports, and the reactivity and stability of these alkyl-zinc and zinc oxide-type sites as a function of zinc dispersion and nuclearity. Additionally, this study presents the use of an organo-zinc pre-catalyst where the initial pre-catalyst ligand (ethyl, C2) is well differentiated from the reacting alkene/alkane (propylene and propene, both $\mathrm{C} 3$ species). This 
approach allowed for the unambiguous monitoring of the activation pathways that the precatalyst undergoes during catalysis. Based on this understanding, optimized synthesis of $\mathrm{Zn} / \mathrm{SiO}_{2}$ catalysts with improved activity and stability have been achieved by ALD.

\section{Experimental Section}

General ALD Synthesis Conditions. Silica ( $\mathrm{SiO}_{2}$, Davisil 646, 40-50 mesh, $300 \mathrm{~m}^{2} / \mathrm{g}$ (BET surface area) and $1.1 \mathrm{cc} / \mathrm{g}$, Sigma-Aldrich) was used as substrate for the gas-phase grafting of $\mathrm{Zn}$ catalysts. The synthesis was performed using an ARRADIANCE Integrated ALD-Catalysis tool (model ARR-100000 GEMSTAR-CAT Dual System). A series of ALD experiments were carried out to ensure the self-limiting nature of the gas-phase deposition reaction (see details in the Supporting Information). 160 to 320 milligrams of $\mathrm{SiO}_{2}$ was loaded into a $406 \mathrm{~mm}$ x $7 \mathrm{~mm}$ (i. d.) stainless steel, plug-flow tube reactor. Unless otherwise stated, the silica substrate for each ALD synthesis experiment was purged with $\mathrm{N}_{2}(10 \mathrm{sccm})$ for 30 minutes after reactor tube installation, and subsequently heated at $200{ }^{\circ} \mathrm{C}$ for $1 \mathrm{~h}$ under vacuum (0.1 Torr). (Note: Silica pretreated under the given conditions is reported to have surface hydroxyl $\left(4.9 \alpha-\mathrm{OH} / \mathrm{nm}^{2} ; 2.44\right.$ mmol $\alpha-\mathrm{OH} / \mathrm{g})$ ). ${ }^{19-21}$ Diethylzinc (DEZ, $>52$ wt.\% Zn basis, Sigma-Aldrich) as ALD precursor and, in some cases, deionized $\mathrm{H}_{2} \mathrm{O}$ was used to protonate the organo-zinc intermediates. Reported thermal growth windows for DEZ- $\mathrm{H}_{2} \mathrm{O}$ ALD range from 25 to $200{ }^{\circ} \mathrm{C} ;{ }^{22}$ The ALD experiments in this study were carried out at 100 and $175{ }^{\circ} \mathrm{C}$ (Note: The substrate temperature reported in this study is temperature reading of the thermocouple attached to the reactor chamber. The actual silica bed temperature is not measured during the ALD process). During the course of ALD synthesis, the manifold upstream of the reactor chamber $\left(\mathbf{M}_{1}-\mathbf{M}_{3}, \mathbf{U M}\right)$ was maintained at $135^{\circ} \mathrm{C}$, the valves downstream of the reactor $(\mathbf{L M})$ at $175^{\circ} \mathrm{C}$. Both the DEZ and $\mathrm{H}_{2} \mathrm{O}$ bottles were kept at ambient temperature during the synthesis. Each ALD precursor pulse 
was carried out in a three-step sequence: (1) manifold evacuation to 1 Torr base pressure (30 s), (2) precursor pulse (10-25 ms) at 1 Torr pressure, and (3) $50 \mathrm{sccm} \mathrm{N}_{2}$ purge (30 s). The progress of the deposition experiment was monitored by detection of ethane using an online residual gas mass spectrometer. (Note: The rate of DEZ delivery is estimated to be $110 \mathrm{mg}(0.89 \mathrm{mmol})$ DEZ/Torr-s. This number is based on the consumption of 5 grams of DEZ over 45 Torr-s). ICPAES analysis of $\mathrm{Zn} / \mathrm{SiO}_{2}$ samples was conducted by Galbraith Laboratories, Inc. (Knoxville, TN) to determine the zinc loading (per weight basis).

$\mathrm{Zn}_{\mathrm{A}}\left[(60 \times 25 \mathrm{~ms}) \mathrm{DEZ}-(60 \times 25 \mathrm{~ms}) \mathrm{H}_{2} \mathrm{O} ; 175^{\circ} \mathrm{C}\right]$. One cycle deposition of $\mathrm{ZnO}$ was carried out using 60 consecutive 25 ms ( 1 Torr) pulses of DEZ followed by 60 consecutive 25 ms ( 1 Torr) pulses of $\mathrm{H}_{2} \mathrm{O}$ on $160 \mathrm{mg} \mathrm{SiO}_{2}(0.39 \mathrm{mmol} \alpha-\mathrm{OH}) .{ }^{19,21}$ Ethane generation during the DEZ pulsing experiments indicates that saturation coverage of the $\mathrm{SiO}_{2}$ substrate by $\mathrm{DEZ}$ is achieved within the first 30 pulses.

$\mathrm{Zn}_{B}\left[(30 \times 25 \mathrm{~ms}) \mathrm{DEZ}-(30 \times 25 \mathrm{~ms}) \mathrm{H}_{2} \mathrm{O} ; 175{ }^{\circ} \mathrm{C}\right]$. One-cycle $\mathrm{ZnO}$ deposition was carried out using 30 consecutive $25 \mathrm{~ms}$ ( 1 Torr) pulses of DEZ followed by 30 consecutive 25 ms (1 Torr) pulses of $\mathrm{H}_{2} \mathrm{O}$ on $160 \mathrm{mg} \mathrm{\textrm {SiO } _ { 2 }}(0.39 \mathrm{mmol} \alpha-\mathrm{OH})$.

$\mathrm{Zn}_{\mathrm{C}} 3\left[(30 \times 25 \mathrm{~ms}) \mathrm{DEZ}-(30 \times 25 \mathrm{~ms}) \mathrm{H}_{2} \mathrm{O} ; 175^{\circ} \mathrm{C}\right]$. Three cycles of zinc oxide deposition were carried out on $160 \mathrm{mg} \mathrm{SiO}_{2}(0.39 \mathrm{mmol} \alpha-\mathrm{OH} 30$ consecutive $25 \mathrm{~ms}$ (1 Torr) DEZ pulses followed by 30 consecutive $25 \mathrm{~ms}$ (1 Torr).

$\mathrm{Zn}_{\mathrm{D}} 10\left[(30 \times 25 \mathrm{~ms}) \mathrm{DEZ}-(30 \times 25 \mathrm{~ms}) \mathrm{H}_{2} \mathrm{O} ; 175{ }^{\circ} \mathrm{C}\right]$. Ten cycles of zinc oxide deposition were carried out on $160 \mathrm{mg} \mathrm{SiO}_{2}(0.39 \mathrm{mmol} \alpha-\mathrm{OH} 30$ consecutive $25 \mathrm{~ms}$ (1 Torr) DEZ pulses followed by 30 consecutive $25 \mathrm{~ms}$ ( 1 Torr) $\mathrm{H}_{2} \mathrm{O}$. 
$\operatorname{Zn}_{E}\left(30 x 25 \mathrm{~ms} D E Z ; 175^{\circ} \mathrm{C}\right)$. One-cycle DEZ deposition was carried out using 30 consecutive 25ms (1 Torr) pulses of DEZ on $160 \mathrm{mg} \mathrm{\textrm {SiO } _ { 2 }}(0.39 \mathrm{mmol} \alpha-\mathrm{OH})$.

$\operatorname{Zn}_{F}\left(30 x 10 \mathrm{~ms} \mathrm{DEZ} ; 175^{\circ} \mathrm{C}\right)$. One-cycle DEZ deposition was carried out using 30 consecutive $10 \mathrm{~ms}$ (1 Torr) pulses of $\mathrm{DEZ}$ on $320 \mathrm{mg} \mathrm{SiO} 2(0.78 \mathrm{mmol} \alpha-\mathrm{OH})$.

$\mathrm{Zn}_{G}\left(30 x 10 \mathrm{~ms} \mathrm{DEZ;} 175{ }^{\circ} \mathrm{C}\right)$. The silica substrate for this experiment was dehydrated at $600{ }^{\circ} \mathrm{C}$ under vacuum ( 0.1 Torr) for $1.5 \mathrm{~h}$ prior to the $\mathrm{ALD}$ experiment. $\mathrm{SiO}_{2}$ dehydration at $600{ }^{\circ} \mathrm{C}$ results in $\alpha-\mathrm{OH}$ concentration of $1.5 / \mathrm{nm}^{2}(0.75 \mathrm{mmol} \alpha-\mathrm{OH} / \mathrm{g})$. One-cycle DEZ deposition was carried out using 30 consecutive $10 \mathrm{~ms}$ (1 Torr) pulses of DEZ on $320 \mathrm{mg} \mathrm{\textrm {SiO } _ { 2 }}(0.24 \mathrm{mmol} \alpha-$ $\mathrm{OH})$.

$\mathrm{Zn}_{\boldsymbol{H}}\left(\mathbf{3 0 x 1 0} \mathrm{ms} \mathrm{DEZ} ; 100{ }^{\circ} \mathrm{C}\right)$. One-cycle DEZ deposition was carried out using 30 consecutive $10 \mathrm{~ms}$ (1 Torr) pulses of DEZ on $320 \mathrm{mg} \mathrm{SiO} 2(0.78 \mathrm{mmol} \alpha-\mathrm{OH})$.

$\mathrm{Zn}_{E t}, \mathrm{SiO}_{2}-\mathrm{Zn}-\mathrm{CH}_{2} \mathrm{CH}_{3}$ Synthesis by Solution Grafting. Solution grafting of DEZ on silica was conducted inside a $\mathrm{N}_{2}$ glove box. A $20 \mathrm{~mL}$ scintillation vial was charged with $500 \mathrm{mg} \mathrm{\textrm {SiO } _ { 2 }}$ (1.22 mmol $\alpha-\mathrm{OH}) ; \mathrm{SiO}_{2}$ dehydrated at $200{ }^{\circ} \mathrm{C}$ prior to solution grafting) ${ }^{19,21} \mathrm{~A} 2 \mathrm{~mL}$ mixed hexanes solution containing $176 \mathrm{mg}(1.42 \mathrm{mmol}) \mathrm{DEZ}$ was then added to the resulting mixture dropwise with constant stirring at room temperature. The reaction mixture was allowed to stir for three hours after the complete addition of DEZ. The resulting mixture was then filtered through a ceramic filter frit and washed three times with $5 \mathrm{~mL}$ portions of hexane. The residue was then dried in vacuo for six hours. The product was characterized by elemental analysis (\% $\mathrm{Zn}$ and C), infrared spectroscopy, X-ray absorption spectroscopy and solid-state, multinuclear $\left({ }^{1} \mathrm{H},{ }^{13} \mathrm{C},{ }^{29} \mathrm{Si}\right)$ magic-angle spinning NMR spectroscopy. 
I-ALD-CAT In Situ Catalysis Studies. The in situ catalyst reactivity experiments were conducted immediately after each ALD catalyst synthesis by switching the I-ALD-CAT tool to “catalysis mode." On-line GC analyses were performed using an Agilent 7890 equipped with a 6-port injection valve, a split/splitless injector and a flame ionization detector. A $60 \mathrm{~m} \times 0.32 \mathrm{~mm}$ GS GasPro capillary column was employed for the separation. GC cycle times were typically 8 minutes. In a typical test, 160 to $320 \mathrm{mg}$ of catalyst generated from the in situ ALD synthesis was tested.

Propylene Hydrogenation. The ALD-synthesized $\mathrm{ZnO}$-type catalyst candidates $\left(\mathrm{Zn}_{\mathrm{A}-\mathrm{D}}\right)$ and the reference catalyst $\mathrm{Zn}_{\mathrm{SEA}}$, were activated with $2.5 \mathrm{~mol} \% \mathrm{H}_{2}$ in $\mathrm{He}$ (Airgas USA, LLC), purified using an oxygen trap, at $40 \mathrm{~mL} / \mathrm{min}$ at $200{ }^{\circ} \mathrm{C}$ for $30 \mathrm{~min}$. After the $\mathrm{H}_{2}$-treatment, the catalyst was fed with $10 \mathrm{~mL} / \mathrm{min} 3.0 \mathrm{~mol} \%$ propylene in $\mathrm{N}_{2}$, maintaining the initial $40 \mathrm{~mL} / \mathrm{min} \mathrm{H}_{2}$ flow. Since the study aims to differentiate the activity of $\mathrm{ZnO}$ - and organozinc-type sites, the supported ethyl-zinc catalysts $\left(\mathrm{Zn}_{\mathrm{E}-\mathrm{H}}\right)$ were tested immediately after the ALD synthesis without a $\mathrm{H}_{2}$ pretreatment step. After the ALD synthesis of the catalyst, the reactor temperature was increased to the desired temperature and was fed with $10 \mathrm{~mL} / \mathrm{min} 3.0 \mathrm{~mol} \%$ propylene in $\mathrm{N}_{2}$ and $40 \mathrm{~mL} / \mathrm{min} \mathrm{H}_{2}$ flow.

Propane Dehydrogenation. The reference catalyst $\mathrm{Zn}_{\text {SEA }}$ was heated to $200{ }^{\circ} \mathrm{C}$ for 30 minutes, maintaining a $40 \mathrm{~mL} / \mathrm{min}$ flow of a $2.5 \mathrm{~mol} \% \mathrm{H}_{2}$ feed. The reactor was then heated to $550{ }^{\circ} \mathrm{C}$ until the temperature is stable, and then fed with $2.5 \%$ propane/Ar at $10 \mathrm{~mL} / \mathrm{min}$. The supported ethyl-zinc catalyst $\left(\mathrm{Zn}_{\mathrm{F}}\right)$ were tested immediately after the ALD synthesis. The reactor temperature was increased to $550{ }^{\circ} \mathrm{C}$ with a constant $40 \mathrm{~mL} / \mathrm{min}$ flow of $\mathrm{N}_{2}$. When the temperature stabilized, the reactor was fed with $2.5 \%$ propane/Ar at $10 \mathrm{~mL} / \mathrm{min}$. 
Infrared Spectroscopy. Infrared (IR) spectra were collected using a Bruker Alpha FTIR spectrometer (Bruker Optics, Billerica, MA) under DRIFTS mode. Spectra at $4 \mathrm{~cm}^{-1}$ resolution were obtained in absorbance mode over the $375-4000 \mathrm{~cm}^{-1}$ range. Air-sensitive samples were characterized in a glove box under a nitrogen atmosphere. All IR data were normalized, baselinecorrected, and analyzed using OPUS (v7.0, Bruker Optics, Billerica, MA) software.

Solid-state Proton Magic-Angle Spinning ( ${ }^{1}$ H MAS) NMR Spectroscopy. Air-sensitive samples were packed into a $1.3 \mathrm{~mm}$ rotor post vacuum dry under an Argon atmosphere. ${ }^{1} \mathrm{H} /{ }^{13} \mathrm{C}$ Cross-Polarization (CP) and ${ }^{1} \mathrm{H}$ Single Pulse Magic Angle Spinning (MAS) Solid-State NMR experiments were performed at 11.7 Tesla on a Bruker Avance spectrometer, operating at Larmor frequencies of $500.13 \mathrm{MHz}$ for ${ }^{1} \mathrm{H}$ and $125.76 \mathrm{MHz}$ for ${ }^{13} \mathrm{C}$, using a $2.5 \mathrm{~mm}$ MAS probe. ${ }^{1} \mathrm{H} /{ }^{13} \mathrm{C}$ CP MAS spectrum was measured at a spinning speed of $20 \mathrm{kHz}$, with a contact time of 4 ms and a recycle delay of $2 \mathrm{~s}$. The RF field strengths for ${ }^{1} \mathrm{H}-{ }^{13} \mathrm{C} \mathrm{CP}$ experiment were $\sim 83.3$ and $\sim 73.5 \mathrm{kHz}$ for ${ }^{1} \mathrm{H}$ and ${ }^{13} \mathrm{C}$, respectively. SPINAL-64 was applied as a heteronuclear decoupling sequence. ${ }^{1} \mathrm{H}$ single pulse experiment was performed at a spinning speed of $20 \mathrm{kHz}$, with a $\pi / 2$ pulse of $2.5 \mu$ s and a recycle delay of $2 \mathrm{~s} .{ }^{1} \mathrm{H} /{ }^{29} \mathrm{Si}$ Cross Polarization (CP) and ${ }^{29} \mathrm{Si}$ Single Pulse Magic Angle Spinning (MAS) Solid-State NMR experiments were performed at 7.05 Tesla on a Bruker Avance III HD spectrometer, operating at Larmor frequencies of $300.13 \mathrm{MHz}$ for ${ }^{1} \mathrm{H}$ and 59.62 MHz for ${ }^{29} \mathrm{Si}$, using a 3.2mm MAS probe. ${ }^{1} \mathrm{H} /{ }^{29} \mathrm{Si} \mathrm{CP}$ MAS spectrum was measured at a spinning speed of $10 \mathrm{kHz}$, with a contact time of $4 \mathrm{~ms}$ and a recycle delay of $2 \mathrm{~s}$. The RF field strengths for ${ }^{1} \mathrm{H}^{-29} \mathrm{Si} \mathrm{CP}$ experiment were $\sim 72$ and $\sim 42.5 \mathrm{kHz}$ for ${ }^{1} \mathrm{H}$ and ${ }^{29} \mathrm{Si}$, respectively. SPINAL-64 was applied as a heteronuclear decoupling sequence. ${ }^{29} \mathrm{Si}$ single pulse experiment was performed at a spinning speed of $10 \mathrm{kHz}$, with a $\pi / 2$ pulse of $5 \mu$ s and a recycle delay of $30 \mathrm{~s}$. 
In all experiments ${ }^{1} \mathrm{H},{ }^{13} \mathrm{C}$ and ${ }^{29} \mathrm{Si}$ chemical shifts were referenced to TMS at $0 \mathrm{ppm}$ and the sample was packed into NMR rotor under an inert atmosphere in a glovebox.

X-ray Absorption Spectroscopy. X-ray absorption spectroscopic characterization (XAS) of various $\mathrm{Zn} / \mathrm{SiO}_{2}$ samples was conducted by $\mathrm{Zn} \mathrm{K}$-edge $(9.659 \mathrm{keV})$ measurements on the bending magnet beamline of the Materials Research Collaborative Access Team (MRCAT, 10$\mathrm{BM}$ ) at the Advanced Photon Source (APS), Argonne National Laboratory. The $\mathrm{Zn} / \mathrm{SiO}_{2}$ samples were pressed into $4 \mathrm{~mm}$ self-supporting wafers and placed in a stainless steel holder. The airsensitive $\mathrm{SiO}_{2}-\mathrm{Zn}-\mathrm{CH}_{2} \mathrm{CH}_{3}$ sample prepared by solution grafting was prepared inside a glove box under a $\mathrm{N}_{2}$ atmosphere, and maintained under air-free conditions throughout the course of the XAS measurement. Each stainless steel holder was placed into a quartz tube (1 in. o.d., 10 in. length) reactor capped with Ultra-Torr fittings equipped with shut-off valves. Both ends of the reactor were sealed with Kapton windows. Samples that required pretreatment prior to XAS measurements were placed in reactors with an internal thermocouple directly touching the sample holder; this thermocouple provided feedback control for the clam-shell furnace used to heat the reactor. The $\mathrm{Zn} / \mathrm{SiO}_{2}$ samples were tested at room temperature after synthesis and under two pretreatment conditions: (1) flowing $\mathrm{H}_{2} / \mathrm{He}(100 \mathrm{cc} / \mathrm{min})$ at $200{ }^{\circ} \mathrm{C}$, and (2) flowing $\mathrm{H}_{2} /$ propylene/He $(100 \mathrm{cc} / \mathrm{min})$ at $200{ }^{\circ} \mathrm{C}$. After sample pretreatment at $200{ }^{\circ} \mathrm{C}$, the XAS measurements were obtained after the catalysts were cooled in He to room temperature without exposure to air. Ionization chambers were optimized at the midpoint of the $\mathrm{Zn}$ spectrum for the maximum current with linear response $\left(\sim 10^{10}\right.$ photons detected $\left.\mathrm{s}^{-1}\right)$ using $5 \% \mathrm{Ar}$ in $\mathrm{N}_{2} \quad(15 \%$ absorption) in the incident $\mathrm{X}$-ray detector and a mixture of $\sim 25 \% \mathrm{Ar}$ in $\mathrm{N}_{2}$ (70\% absorption) in the transmission X-ray detector. A third detector in the series simultaneously collected a $\mathrm{Zn}$ foil reference spectrum with each measurement for energy calibration. A cryogenically cooled 
double-crystal $\mathrm{Si}(111)$ monochromator was used and detuned to $50 \%$ to minimize higher harmonics. The X-ray beam was $0.5 \times 1.5 \mathrm{~mm}$, and data were collected in transmission geometry over 10 min in step-scan mode.

The Zn K-edge XANES energy was determined from the inflection point of the leading edge by determination of the energy of the maximum in the first peak of the first derivative. Extended X-ray absorption fine structure (EXAFS) fits of the Zn/silica catalysts were determined from experimental phase shift and backscattering amplitudes using standard procedures within WINXAS 3.1 software. The EXAFS coordination parameters were obtained by least-squares fit in r-space of the first shell nearest neighbor, $\mathrm{k}^{2}$-weighted Fourier transform data. Zn-O phase and amplitude were obtained from a Würtzite $\mathrm{ZnO}$ reference ( $3 \mathrm{Zn}-\mathrm{O}$ bonds at $1.974 \AA$ and $1 \mathrm{Zn}-\mathrm{O}$ bond at $1.988 \AA$ ): the $\mathrm{k}^{2}$-weighted Fourier transformed spectrum was reverse-transformed over the range $0.96-2.16 \AA$ to select for first-shell $\mathrm{Zn}-\mathrm{O}$ scattering, and the resulting phase and amplitude used to define a scattering reference for $4.0 \mathrm{Zn}-\mathrm{O}$ bonds at $1.98 \AA$. $\mathrm{Zn}$-C phase and amplitude were obtained from $\mathrm{ZnEt}_{2}(2 \mathrm{Zn}-\mathrm{C}$ bonds at $1.95 \AA)$ : the $\mathrm{k}^{2}$-weighted Fourier transformed spectrum was reverse-transformed over the range $0.84-2.04 \AA$, and the resulting phase and amplitude used to define a scattering reference for $2.0 \mathrm{Zn}-\mathrm{C}$ bonds at $1.95 \AA$. These scattering references were then used to fit $\mathrm{Zn}-\mathrm{O}$ and $\mathrm{Zn}-\mathrm{C}$ scattering contributions to samples of interest. Reported $\Delta \sigma^{2}$ values are defined as $\Delta \sigma^{2}=\sigma^{2}$ (sample) $-\sigma^{2}$ (reference), where the value of $\sigma^{2}$ (reference) is implicitly contained within the reference phase and amplitude data. A $\Delta \sigma^{2}$ value near zero indicates that sample and reference have similar values for the pseudo-Debye Waller factor. Absolute values of $\sigma^{2}$ were not determined in general; examination of selected spectra applying FEFF 6.0 calculations within the Artemis software package to experimental crystal structures suggested absolute values for $\sigma^{2}$ of 0.0025 for $\mathrm{Zn}-\mathrm{C}$ first shell scattering in $\mathrm{ZnEt}_{2}$ and 
0.0031 for $\mathrm{Zn}-\mathrm{O}$ first shell scattering in $\mathrm{ZnO}$. Transfer of experimentally measured backscattering amplitudes from references to samples directly accounts for the energy-dependent variation in scattering amplitude for each scattering path, obviating the need for the $\mathrm{S}_{\mathrm{o}}{ }^{2}$ correction factor. Examination of selected spectra within Artemis suggested an $\mathrm{S}_{\mathrm{o}}{ }^{2}=0.80$ for both $\mathrm{Zn}-\mathrm{O}$ and $\mathrm{Zn}-\mathrm{C}$.

X-ray diffraction. Crystalline phase compositions of the $\mathrm{ALD}$-synthesized $\mathrm{Zn} / \mathrm{SiO}_{2}$ samples were determined by powder X-ray diffraction using a Bruker Diffractometer D8 Advance operating with the following parameters: $\mathrm{Cu} \mathrm{K} \alpha$ radiation of $40 \mathrm{~mA}, 40 \mathrm{kV}, \mathrm{K}_{\lambda}=0.15418 \mathrm{~nm}$, $2 \theta$ scanning range of $5-70^{\circ}$, a scan step size of $0.005^{\circ}$ and a time of 3 s per step. The samples were ground and placed on a zero background silicon holder (MTI Corp.) for analysis.

Transmission Electron Microscopy (TEM). High Resolution TEM images were obtained at the University of Illinois-Chicago's Research Resources Center facility using the JEM-3010 (a $300 \mathrm{kV}$ transmission electron microscope with a $\mathrm{LaB}_{6}$ electron source). The JEM-3010 is an ultrahigh resolution analytical electron microscope with a point resolution of $0.17 \mathrm{~nm}$. Each sample was dispersed in deionized water and sonicated for $20 \mathrm{~min}$. A drop of the suspension was added to a holey-carbon copper grid and dried under a heat lamp for $10 \mathrm{~min}$. Imaging was performed in bright field mode with an objective aperture selected to permit lattice imaging. A minimum of 100 particles were counted to get an accurate representation of the particle size distribution for each catalyst using Digital Micrograph software.

Density Functional Theory Computational Methods. First-principles calculations based on the hybrid density functional theory $(\mathrm{B} 3 \mathrm{LYP})^{23}$ were conducted to simulate the mechanism of ethyl group activation on zinc under catalytic conditions. The catalyst surface was simulated using cluster models representing silsesquioxane cage structures. Such models have been successfully 
used in our previous studies. ${ }^{4 a}$ The structure optimizations and free energy calculations of different reaction intermediates and transition states were performed using the Gaussian-09 quantum chemistry software. ${ }^{24}$ The accuracy of the transition state (TS) calculations was verified through intrinsic reaction coordinate (IRC) $\mathrm{scans}^{25}$ and frequency analysis. TZVP basis sets were used to perform the calculations (B3LYP/TZVP) ${ }^{26}$

\section{Results and Discussion}

Catalyst synthesis by ALD. Various zinc on silica catalysts were synthesized by ALD using diethylzinc (DEZ) as precursor and, in some cases, water in a subsequent synthesis step (Figure 4). The self-limiting nature of the gas-phase grafting technique was verified through a series of $\mathrm{ZnO}$ deposition experiments under surface saturating conditions. Table $\mathbf{1}$ summarizes the results of these ALD synthesis experiments on silica pre-dried at $200{ }^{\circ} \mathrm{C}\left(4.9 \alpha-\mathrm{OH} / \mathrm{nm}^{2}\right) \cdot{ }^{19,21}$ In this paper, a complete zinc oxide monolayer is defined as the material generated from the reaction of one equivalent of DEZ with one equivalent of surface hydroxyl groups $(\alpha-\mathrm{OH})$. One-cycle $\mathrm{ZnO}$ deposition experiments employing total DEZ doses of 0.75 Torr-s and 1.5 Torr-s on $160 \mathrm{mg} \mathrm{\textrm {SiO } _ { 2 }}$ $(0.39 \mathrm{mmol} \alpha-\mathrm{OH})$ afforded $\mathrm{Zn}_{\mathrm{A}}$ and $\mathrm{Zn}_{\mathrm{B}}$ (Table 1), respectively. ICP-AES analysis of $\mathrm{Zn}_{\mathrm{A}}$ and $\mathrm{Zn}_{\mathrm{B}}$ revealed identical zinc loadings of $10 \%$ (per weight basis; $0.29 \mathrm{mmol}$ ). The identical zinc loading despite the difference in total DEZ dosage employed in the ALD synthesis confirms the self-limiting nature of the zinc oxide deposition. ${ }^{27-29}$ The self-limiting deposition reaction is also supported by findings from the mass spectrometric monitoring of the reaction between silica and excess amount of DEZ at $100{ }^{\circ} \mathrm{C}$ and $175{ }^{\circ} \mathrm{C}$ (see Figures S1 to S3 in the Supporting Information).

The observed $10 \% \mathrm{Zn}$ loading $(0.29 \mathrm{mmol} \mathrm{Zn})$ suggests that, during the first ALD halfreaction, silica surface saturation by ethyl-zinc(II) species constitutes $\sim 75 \%$ of a theoretical 
monolayer $(0.39 \mathrm{mmol} \mathrm{Zn})$. This coverage limit is attributed to steric crowding of ethyl-zinc(II) fragments on the silica surface. (Note: The 0.75 Torr-s ALD method for $\mathrm{Zn}_{\mathrm{B}}$ is estimated to deliver $\sim 83 \mathrm{mg}(0.67 \mathrm{mmol}) \mathrm{DEZ}$. The $0.29 \mathrm{mmol} \mathrm{Zn}$ on $\mathrm{Zn}_{\mathrm{B}}$ constitutes to $43 \%$ of the total $\mathrm{Zn}$ pulsed. The rate of DEZ delivery is estimated to be $110 \mathrm{mg}(0.89 \mathrm{mmol})$ DEZ/Torr-s. This number is based on the consumption of 5 grams of DEZ over 45 Torr-s). Analysis of the top and bottom regions of the $\mathrm{Zn}_{\mathrm{B}}$ bed revealed $\mathrm{Zn}$ loadings of $12 \%$ and $10 \%$, respectively, both of which are consistent with submonolayer coverage by Zn species and an ALD-type deposition mechanism. Three successive $\mathrm{ZnO}$ cycles gave $\mathrm{Zn}_{\mathrm{C}}$ (Table 1) with $27 \% \mathrm{Zn}$. This $\mathrm{Zn}$ content suggests that, on the average, $19 \mathrm{mg}(0.29 \mathrm{mmol}) \mathrm{Zn}$ is deposited per $\mathrm{ZnO}$ deposition cycle. This result is a demonstration of the reproducibility of the ALD synthesis method.

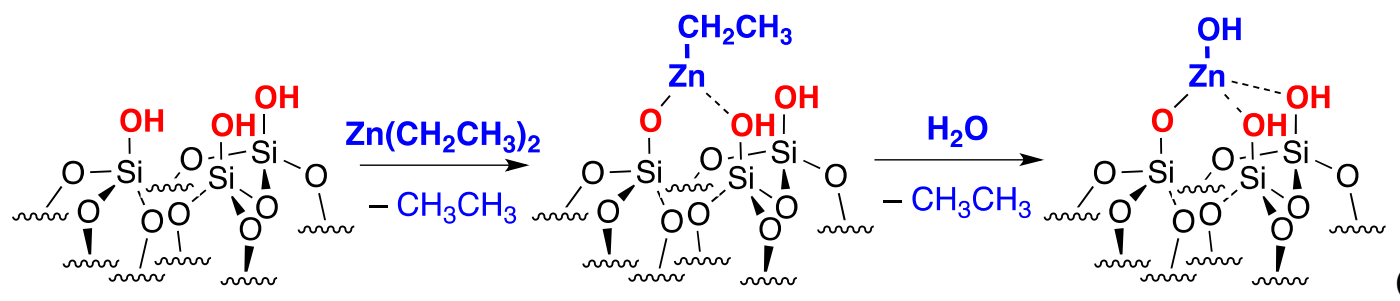

(a)

(b)

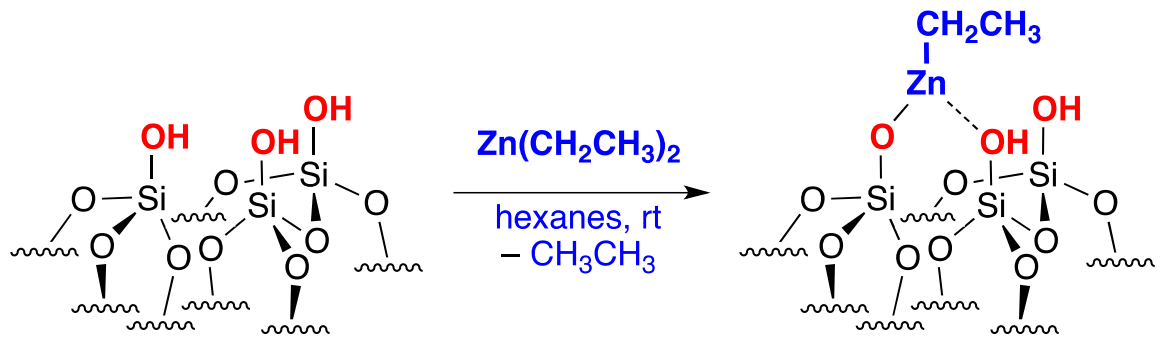

Scheme 1. (1) Synthesis of $\mathrm{Zn} / \mathrm{SiO}_{2}$ via atomic layer deposition at $175^{\circ} \mathrm{C}$. (2) Synthesis of $\mathrm{H}_{3} \mathrm{CH}_{2}-\mathrm{Zn} / \mathrm{SiO}_{2}\left(\mathbf{Z n}_{\mathbf{E t}}\right)$ via solution grafting.

Table $1 . \mathrm{Zn} / \mathrm{SiO}_{2}$ synthesis by atomic layer deposition.

\begin{tabular}{|l|c|c|c|c|c|}
\hline \multicolumn{1}{|c|}{$\begin{array}{c}\text { ALD Synthesis } \\
\text { Method }\end{array}$} & $\begin{array}{c}\text { ALD } \\
\text { Cycle(s) }\end{array}$ & $\begin{array}{c}\text { Temperature } \\
\left({ }^{\circ} \mathbf{C}\right)\end{array}$ & $\begin{array}{c}\mathbf{S i O}_{2} \\
(\mathbf{m g})\end{array}$ & $\begin{array}{c}\mathbf{Z n} \\
(\mathbf{w t} \\
\mathbf{\%})\end{array}$ & $\begin{array}{c}\text { Type of } \mathbf{Z n} \\
\text { species formed }\end{array}$ \\
\hline $\begin{array}{l}\mathbf{Z n}_{\mathrm{A}}[1.5 \text { Torr-s DEZ) }+ \\
\left.\left(1.5 \text { Torr-s } \mathrm{H}_{2} \mathrm{O}\right)\right]\end{array}$ & 1 & 175 & 160 & 10 & $\begin{array}{c}\text { Monodispersed } \\
\text { zinc oxide sites } \\
(\text { submonolayer })\end{array}$ \\
\hline $\mathbf{Z n}_{\mathbf{B}}[(0.75$ Torr-s DEZ) & 1 & 175 & 160 & 10 & \\
\hline
\end{tabular}




\begin{tabular}{|c|c|c|c|c|c|}
\hline$+\left(0.75\right.$ Torr-s $\left.\left.\mathrm{H}_{2} \mathrm{O}\right)\right]$ & & & & & \\
\hline $\begin{array}{l}\mathbf{Z} \mathbf{n}_{\mathbf{C}}[(0.75 \text { Torr-s DEZ }) \\
\left.+\left(0.75 \text { Torr-s } \mathrm{H}_{2} \mathrm{O}\right)\right]\end{array}$ & 3 & 175 & 160 & 27 & \multirow[t]{2}{*}{ film } \\
\hline $\begin{array}{l}\mathbf{Z} \mathbf{n}_{\mathbf{D}}[(0.75 \text { Torr-s DEZ }) \\
\left.+\left(0.75 \text { Torr-s } \mathrm{H}_{2} \mathrm{O}\right)\right]\end{array}$ & 10 & 175 & 160 & 49 & \\
\hline $\mathbf{Z n}_{\mathbf{E}}(0.75$ Torr-s DEZ) & 1 & 175 & 160 & 10 & \multirow{4}{*}{$\begin{array}{l}\text { ethylzinc(II } \\
\text { sites }\end{array}$} \\
\hline $\mathbf{Z n}_{\mathbf{F}}(0.3$ Torr-s DEZ $)$ & 1 & 175 & 320 & 2.2 & \\
\hline $\mathbf{Z n}_{\mathbf{G}}(0.75$ Torr-s DEZ) & 1 & 175 & 320 & 4.5 & \\
\hline $\mathbf{Z n}_{\mathbf{H}}(0.3$ Torr-s DEZ) & 1 & 100 & 320 & 3.7 & \\
\hline
\end{tabular}

The zinc oxide-type sites generated from the ALD synthesis were characterized via diffuse-reflectance infrared Fourier-Transform spectroscopy (DRIFTS) and X-ray absorption spectroscopy (XAS), and were found to be isolated tetracoordinate $\mathrm{Zn}$ (II) sites on silica (b, Figure 4). On the other hand, since the product of the first ALD half reaction (b, Eq. 1 in Scheme 1) is air-sensitive and cannot be transported out of the I-ALD tool under inert-atmosphere conditions, spectroscopic characterization of ethyl-zinc on silica was carried out using the product generated from the room-temperature solution grafting of DEZ on silica $\left(\mathrm{Zn}_{\mathrm{Et}}, \mathrm{Eq} .2\right.$, Scheme 1). Spectroscopic characterization of $\mathrm{Zn}_{\mathrm{Et}}$ (vide infra) revealed a tricoordinate configuration for the ethyl-zinc/SiO 2 species. Detailed discussion of the spectroscopic data for both zinc species will be presented in the latter section of this paper.

Catalytic Propylene Hydrogenation Activity. The catalytic activities of the ALD-synthesized $\mathrm{Zn} / \mathrm{SiO}_{2}$ systems were investigated for propylene hydrogenation and propane dehydrogenation under plug-flow conditions, with the I-ALD-CAT tool in "catalysis mode". Each catalyst performance evaluation was carried out immediately after the in situ catalyst synthesis by ALD. This feature of the I-ALD-CAT tool allows for systematic comparison of the catalytic reactivity of zinc oxide and alkyl zinc-type active sites without exposure to air and moisture during the course of the experiment. Our group recently reported a single-site $\mathrm{Zn} / \mathrm{SiO}_{2}$ catalyst prepared by strong electrostatic adsorption (SEA) of $\left[\mathrm{Zn}\left(\mathrm{NH}_{3}\right)_{4}\right]^{2+} \mathbf{Z n}_{\text {SEA }}$ that hydrogenates propylene at 200 
${ }^{\circ} \mathrm{C}$ with the $\mathrm{Zn}$ (II) sites functioning as Lewis acid centers that heterolytically activate $\mathrm{H}-\mathrm{H}$ and $\mathrm{C}-\mathrm{H}$ bonds under hydrogenation and dehydrogenation conditions, respectively. ${ }^{4 a}$ Homogeneous and heterogeneous zinc materials that either catalytically or stoichiometrically hydrogenate olefins are rare. ${ }^{31-33,36}$ Of the few stoichiometric systems that insert an olefin into a $\mathrm{Zn}-\mathrm{H}$ bond, promoter complexes of $\mathrm{Ti}$ or $\mathrm{Ni}$ are necessary. ${ }^{36-37} \mathrm{Zn} / \mathrm{ZSM}-5$, on the other hand, lacks olefin hydrogenation activity since olefin polymerization by the protons in the catalyst framework is more favorable. ${ }^{4 a}$ Similar to $\mathrm{Zn}_{\mathrm{SEA}}$, the ALD-synthesized catalysts required high hydrogenation temperatures $\left(>150{ }^{\circ} \mathrm{C}\right.$; Note: Propylene hydrogenation results presented in this section were obtained at $\left.200{ }^{\circ} \mathrm{C}\right) .{ }^{4 a}$ The catalysts are $100 \%$ selective to propane, with no other hydrocarbon products observed. The $\mathrm{SiO}_{2}$ support is unreactive under the given conditions while the ALDsynthesized $\mathrm{Zn} / \mathrm{SiO}_{2}$ catalysts exhibit various rates of deactivation as influenced by $\mathrm{Zn}$ loading and $\mathrm{SiO}_{2}$ pretreatment conditions. Interestingly, the ALD catalyst synthesis methods that involve water treatment of the ethyl zinc submonolayer on $\mathrm{SiO}_{2}$ generate unstable, low-reactivity materials. For example, a submonolayer of monodispersed $\mathrm{ZnO}$ on $\mathrm{SiO}_{2}\left(\mathbf{Z n}_{\mathbf{B}}\right)$, hydrogenates propylene but deactivates completely in the first 30 minutes of the reaction. The low activity and stability of $\mathrm{Zn}_{\mathrm{B}}$ is attributed to the facile agglomeration of the $\mathrm{Zn}$ sites, forming $\mathrm{ZnO}$ clusters which are inactive for hydrogenation under the given conditions. ${ }^{30-34}$ This is consistent with TEM images of $\mathrm{Zn}_{\mathrm{B}}$ which show the presence of $\sim 20 \mathrm{~nm} \mathrm{ZnO}$ particles (a, Figure 3). This mode of $\mathrm{ZnO}$ speciation is consistent with reported island-like nucleation of $\mathrm{ZnO}$ on oxide supports. ${ }^{30}$ Our work shows that the formation of island-nuclei appears to occur during the water pulse, with the initial ethyl-zinc surface species being well-dispersed. Conformal $\mathrm{ZnO}$ sub-monolayer deposition cannot be completely ruled out since the observed particles may have formed upon exposure to the atmosphere prior to TEM imaging. Moreover, varying degrees of particle 
formation were also observed in several spent $\mathrm{Zn} / \mathrm{SiO}_{2}$ catalysts (vide infra) further confirming the mobility of $\mathrm{Zn}(\mathrm{II})$ sites on the silica surface.

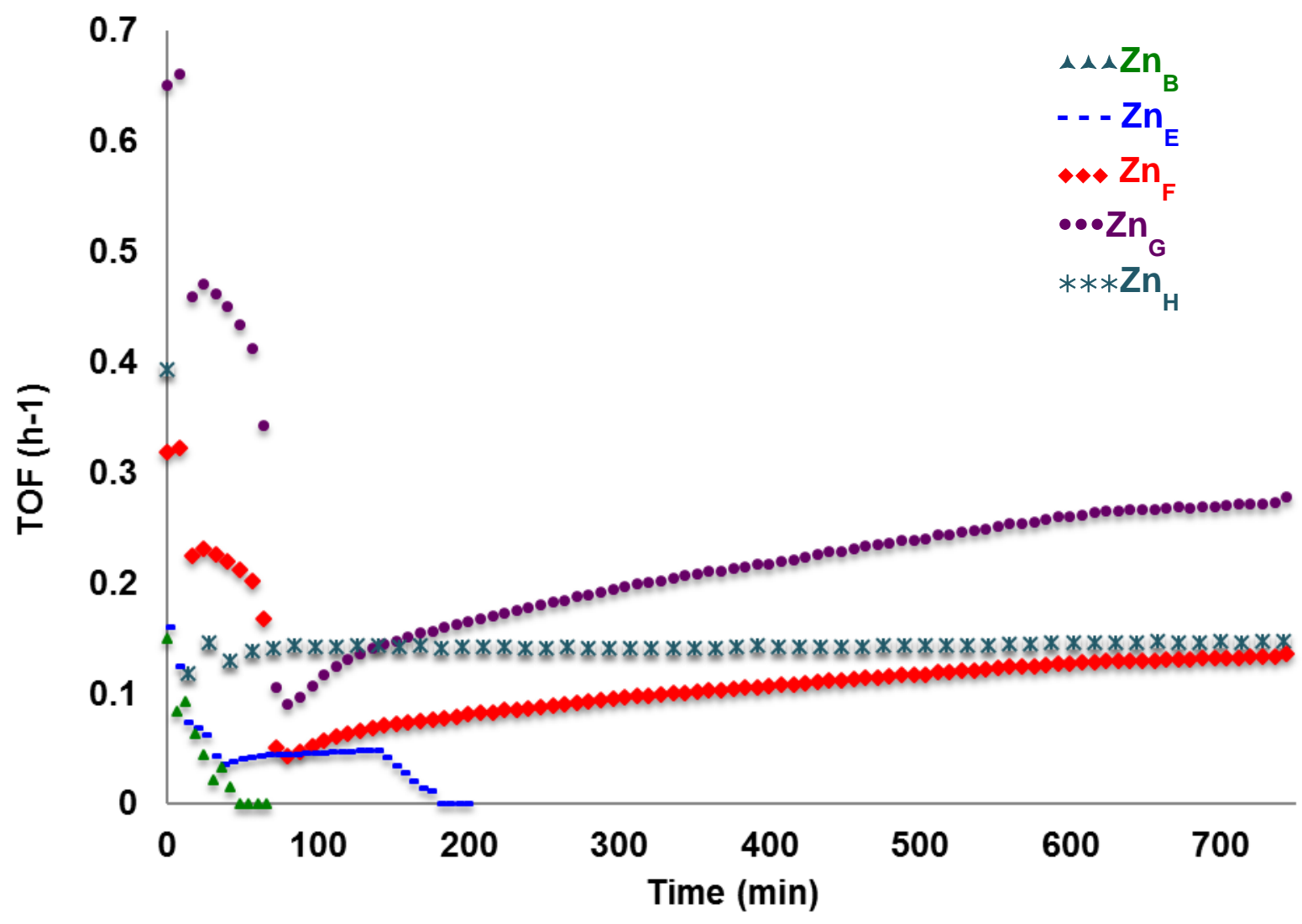

Figure 4. Hydrogenation of propylene reactivity of $\mathrm{Zn}_{\mathrm{B}}, \mathrm{Zn}_{\mathrm{E}}, \mathrm{Zn}_{\mathrm{F}}, \mathrm{Zn}_{\mathrm{G}}$ and $\mathrm{Zn}_{\mathrm{H}}$ at $200{ }^{\circ} \mathrm{C}$. The apparent TOF was calculated based on the total amount of $\mathrm{Zn}$ present in the catalyst.

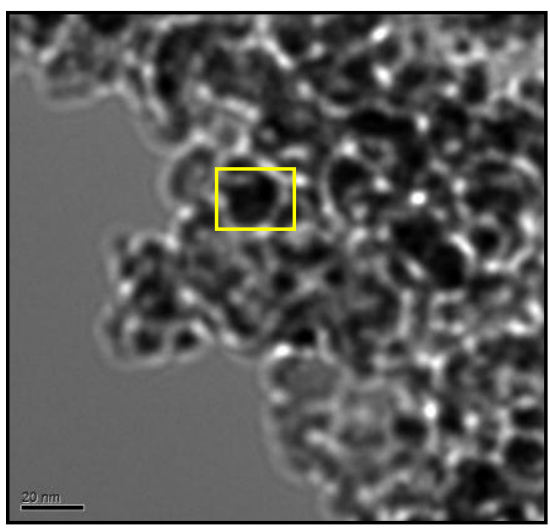

$\mathbf{a}(<20 \mathrm{~nm})$

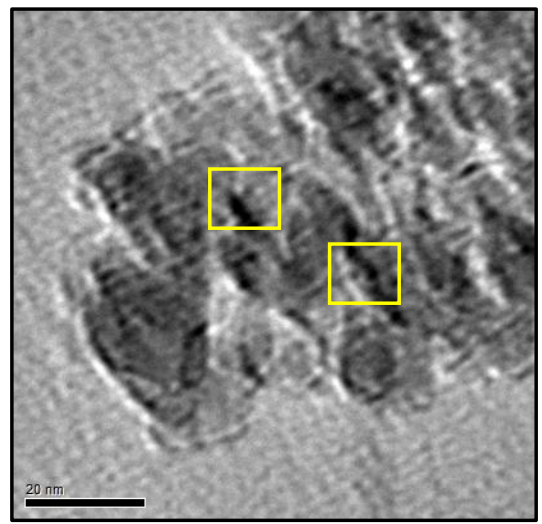

b $(3-5 \mathrm{~nm})$ 


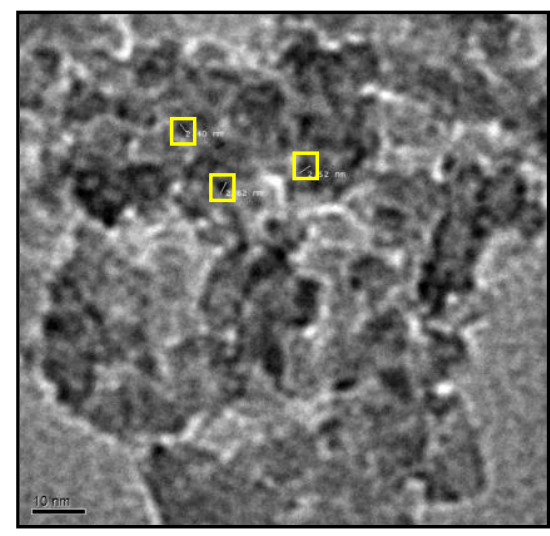

c $(2-3 \mathrm{~nm})$

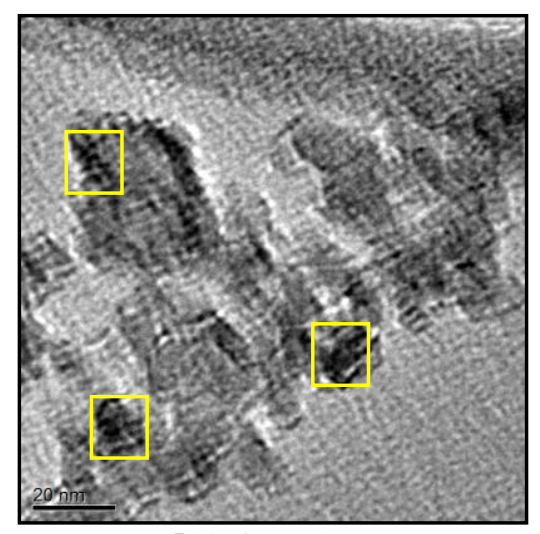

d(1-2 nm)

Figure 3. Bright Field TEM images of $\mathrm{Zn} / \mathrm{SiO}_{2}$ synthesized by ALD. (a) $\mathrm{Zn}_{\mathrm{B}}$, (b) $\mathrm{Zn}_{\mathrm{E}}$ (spent), (c) $\mathrm{Zn}_{\mathrm{F}}$ (spent) and (d) $\mathrm{Zn}_{\mathrm{G}}$ (spent).

The propylene hydrogenation activity of ethyl zinc sites on silica was also evaluated. $\mathrm{Zn}_{\mathrm{E}}$, with $\mathrm{Zn}$ loading identical to $\mathrm{Zn}_{\mathrm{B}}$ (Table 1), is catalytically inactive at room temperature and exhibits hydrogenation activity above $150{ }^{\circ} \mathrm{C}$. $\mathrm{Zn}_{\mathrm{E}}$ hydrogenates propylene at $200^{\circ} \mathrm{C}\left(\mathrm{TOF}_{0 \mathrm{~h}}=0.159 \mathrm{~h}^{-1}\right.$, $\mathrm{TOF}_{3 \mathrm{~h}}=0.012 \mathrm{~h}^{-1}$; Fig. 4), however, it completely deactivates in $\sim 3 \mathrm{~h}$ due to $\mathrm{Zn}$ agglomeration (3-5 nm particles; b, Figure 3). Notably, $\mathrm{Zn}_{\mathrm{E}}$ exhibits higher initial hydrogenation activity compared to $\mathrm{Zn}_{\mathrm{B}}$. The observed disparity in the initial hydrogenation activities $(\mathrm{t}<80 \mathrm{~min})$ between these $\mathrm{Zn} / \mathrm{SiO}_{2}$ with identical $\mathrm{Zn}$ loadings ( $75 \%$ of a monolayer) is attributed to differences in the precatalyst structure: One-cycle DEZ- $\mathrm{H}_{2} \mathrm{O}$ experiment generates $\mathrm{Zn}_{\mathrm{B}}$ with closed shell 18-electron, tetracoordinate $\mathrm{Zn}$ (II) centers. The higher initial activity of $\mathrm{Zn}_{\mathrm{E}}$, on the other hand, is expected for the open-shell 16-electron, tricoordinate ethyl zinc(II) sites present. These open-shell $\mathrm{Zn}(\mathrm{II})$ sites are expected to exhibit enhanced substrate binding affinity while the zinc-ethyl functionality is a reactive site that can heterolytically activate hydrogen (vide infra). In contrast to $\mathrm{Zn}_{\mathrm{B}}, \mathrm{Zn}_{\mathrm{SEA}}$ and bulk $\mathrm{ZnO}$, catalyst $\mathrm{Zn}_{\mathrm{E}}$ does not require high-temperature pretreatment conditions, consistent with the higher reactivity for supported alkyl zinc species under similar conditions. Overall, the hydrogenation activity of $\mathrm{Zn}_{\mathrm{E}}$ confirms that supported alkyl zinc species provide a convenient entry into the catalytic cycle. 
The observed facile deactivation of $\mathrm{Zn}_{\mathrm{B}}$ and $\mathrm{Zn}_{\mathrm{E}}$ suggests that $\mathrm{Zn}($ II) isolation is the key factor to access stable catalysts. Hence, optimization of ALD synthesis conditions (e.g. substrate preparation, DEZ dose) was conducted to increase active site dispersion and, in turn, produce catalysts with improved activity and stability. Reducing the DEZ dosing time from 0.75 Torr-s to 0.3 Torr-s and doubling the substrate loading (320 mg) afforded catalyst $\mathrm{Zn}_{\mathrm{F}}(2.2 \% \mathrm{Zn}$; Table 1) with increased activity $\left(\mathrm{TOF}_{0 \mathrm{~h}}=0.650 \mathrm{~h}^{-1}, \mathrm{TOF}_{12 \mathrm{~h}}=0.280 \mathrm{~h}^{-1}\right.$, Fig. 4) and longer catalyst life. $\mathrm{Zn}_{\mathrm{F}}$ deactivates, retaining only $31 \%$ of its initial activity after a 12 -hour reaction period. TEM imaging of spent catalyst $\mathrm{Zn}_{\mathrm{F}}$ revealed the formation of smaller $\mathrm{ZnO}$ particles $(2 \mathrm{~nm}$; $\mathbf{c}$ in Figure 3), indicative of slower agglomeration and retained monodispersity of majority of the $\mathrm{Zn}(\mathrm{II})$ sites. The single-site nature of majority of the $\mathrm{Zn}$ sites in catalyst $\mathrm{Zn}_{\mathrm{F}}$ post-catalysis is confirmed by EXAFS data where second-shell scattering due to sintered $\mathrm{Zn}$ sites were not observed.

Silica dehydration in vacuo at $600{ }^{\circ} \mathrm{C}$ to reduce surface hydroxyl concentration also

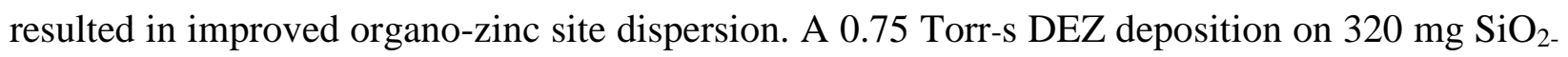
$600{ }^{\circ} \mathrm{C}$ generates catalyst $\mathrm{Zn}_{\mathrm{G}}(4.5 \% \mathrm{Zn}$, Table 1) with improved hydrogenation activity compares to $\mathrm{Zn}_{\mathrm{E}}\left(\mathrm{TOF}_{0 \mathrm{~h}}=0.318 \mathrm{~h}^{-1}, \mathrm{TOF}_{12 \mathrm{~h}}=0.137 \mathrm{~h}^{-1}\right) . \mathrm{Zn}_{\mathrm{G}}$ exhibits improved stability, retaining $42 \%$ of the initial activity after 12 hours of testing (Fig. 7). Post-catalysis images of $\mathrm{Zn}_{\mathrm{G}}$ support improved $\mathrm{Zn}$ dispersion based on the smaller particles observed (1-2 nm; d in Figure 3).

The effect of the deposition temperature on catalytic reactivity was also explored. 0.3 Torr-s DEZ was grafted at $100{ }^{\circ} \mathrm{C}$, affording $\mathrm{Zn}_{\mathrm{H}}$ (Table 1) with $3.7 \% \mathrm{Zn}(\mathrm{wt}$ ). The resulting material exhibits lower hydrogenation activity $\left(\mathrm{TOF}_{0 \mathrm{~h}}=0.393 \mathrm{~h}^{-1}, \mathrm{TOF}_{0 \mathrm{~h}}=0.167 \mathrm{~h}^{-1}\right)$ relative to $\mathrm{Zn}_{\mathrm{F}}(2.2 \% \mathrm{Zn})$, which was synthesized at $175^{\circ} \mathrm{C}$. The observed lower zinc deposition at $175^{\circ} \mathrm{C}$ suggests that self-decomposition of DEZ that can lead to CVD is not a major factor during the one-cycle Zn deposition experiments employed in this study. An earlier report by Weimer and 
coworkers suggests that $\mathrm{DEZ}-\mathrm{H}_{2} \mathrm{O}$ at $177{ }^{\circ} \mathrm{C}$ resulted in variations in $\mathrm{Zn}$ loading due to $\mathrm{DEZ}$ self-decomposition at high temperatures. ${ }^{38}$ However, they also emphasized that selfdecomposition only becomes a challenge under conditions where overexposure of DEZ to decomposing temperatures (e.g., 10 cycle DEZ- $\mathrm{H}_{2} \mathrm{O}$ deposition or more) occurs. ${ }^{38}$ The higher zinc loading $(3.7 \%)$ at a lower temperature $\left(100{ }^{\circ} \mathrm{C}\right)$ is attributable to higher surface hydroxyl concentration on the silica substrate resulting in the formation of catalytically inactive zinc clusters. This aspect presents the advantage of high-temperature, gas-phase organometallic grafting for the nucleation of single-atom sites over traditional liquid- and gas-phase techniques under ambient conditions; isolated catalytic sites can be grafted under conditions that allow for thermal control of surface hydroxyl concentrations. Reference catalyst $\mathrm{Zn}_{\mathrm{SEA}}$, with $\mathrm{Zn}$ loading similar to $\mathrm{Zn}_{\mathrm{H}}(4 \% \mathrm{Zn})$, show lower activity under the given conditions $\left(\mathrm{TOF}_{0 \mathrm{~h}}=0.107 \mathrm{~h}^{-1}\right.$, $\mathrm{TOF}_{12 \mathrm{~h}}=0.043 \mathrm{~h}^{-1}$ ) Note: Due to instrument design limitations, the conditions employed in the previously reported $\mathrm{Zn}_{\mathrm{SEA}}$-catalyzed hydrogenation study ${ }^{4 \mathrm{a}}$ cannot be implemented in the present study. Slower flow rates were employed in the catalysis experiments. The slower $\mathrm{Zn}_{\text {SEA }}$ hydrogenation rates reported in this study are due to a shorter contact time employed (1.3 s); This is almost half of that employed in our previous report $(\sim 2.0 \mathrm{~s}) .^{4 \mathrm{a}}$

Interestingly, the period where higher initial activity with catalysts $\mathrm{Zn}_{\mathrm{E}-\mathrm{H}}$ was observed(t $<80 \mathrm{~min}$ ) coincides with active generation of $\mathrm{C}_{2}$ and $\mathrm{C}_{4}$ hydrocarbons, further confirming that supported alkyl zinc species provide reasonable entry into the catalytic hydrogenation cycle. Notably, systems with increased $\mathrm{Zn}$ dispersity $\left(\mathrm{Zn}_{\mathrm{F}-\mathrm{G}}\right)$ exhibit long-term activity $(\mathrm{t}>12 \mathrm{~h})$ with $\mathrm{Zn}_{\mathrm{F}}$ and $\mathrm{Zn}_{\mathrm{G}}$ exhibiting enhanced activity over time. This is an indication of the dynamic nature of these surface sites under reaction conditions, however, no definitive explanation can be offered yet for this phenomenon. 
Catalytic Propane Dehydrogenation Activity. Catalytic propane dehydrogenation activity was determined at $550{ }^{\circ} \mathrm{C}$ as equilibrium conversion is reasonable ( $\left.\sim 30 \%\right)$, while thermal cracking contributions at this temperature are minimal. ${ }^{4 a}$ Both zinc oxide- and ethylzinc(II)-saturated $\mathrm{SiO}_{2}$ catalysts $\left(\mathrm{Zn}_{\mathrm{B}}\right.$ and $\mathrm{Zn}_{\mathrm{E}}$, respectively) are inactive for propane dehydrogenation at $550{ }^{\circ} \mathrm{C}$. The lack of activity is attributable to $\mathrm{Zn}$ sintering to $\mathrm{ZnO}$ clusters that are known to be inactive for propane dehydrogenation. ${ }^{39}$ The more dispersed ethylzinc(II) sites in $\mathrm{Zn}_{\mathrm{F}}$, on the other hand, selectively dehydrogenates propane $\left(\mathrm{TOF}_{0 \mathrm{~h}}=0.103 \mathrm{~h}^{-1}, \mathrm{TOF}_{12 \mathrm{~h}}=0.042 \mathrm{~h}^{-1}\right.$; Fig. 5) over a 12 hour period. Since the study aims to differentiate the dehydrogenation activity of $\mathrm{ZnO}$ (e.g., $\left.\mathrm{Zn}_{\mathrm{SEA}}\right)$ and ethyl-zinc-type sites $\left(\mathrm{Zn}_{\mathrm{F}}\right)$, catalyst $\mathrm{Zn}_{\mathrm{F}}$ was tested for propane dehydrogenation immediately after the ALD synthesis without the pre-activation with $\mathrm{H}_{2}$ step implemented for $\mathrm{Zn}_{\text {SEA }}$. Lower selectivites for propylene (30-70\%) were observed for $\mathrm{Zn}_{\mathrm{F}}$ in the first $~ 90$ minutes of testing since this period coincides with the generation of ethane and ethylene from the activation of the ethyl-zinc/SiO ${ }_{2}$ precatalyst. At $\mathrm{t}>90 \mathrm{~min}$, higher selectivities to propylene (78\% selectivity to propylene) were observed; however, propylene selectivity decreases to $65 \%$ by the end of the 12 hour reaction period. Under identical conditions, $\mathrm{Zn}_{\mathrm{SEA}}$ exhibits lower activity $\left(\mathrm{TOF}_{0 \mathrm{~h}}=0.071 \mathrm{~h}^{-1}, \mathrm{TOF}_{12 \mathrm{~h}}=0.020 \mathrm{~h}^{-1}\right)$ and propylene selectivity (Fig. 5). 


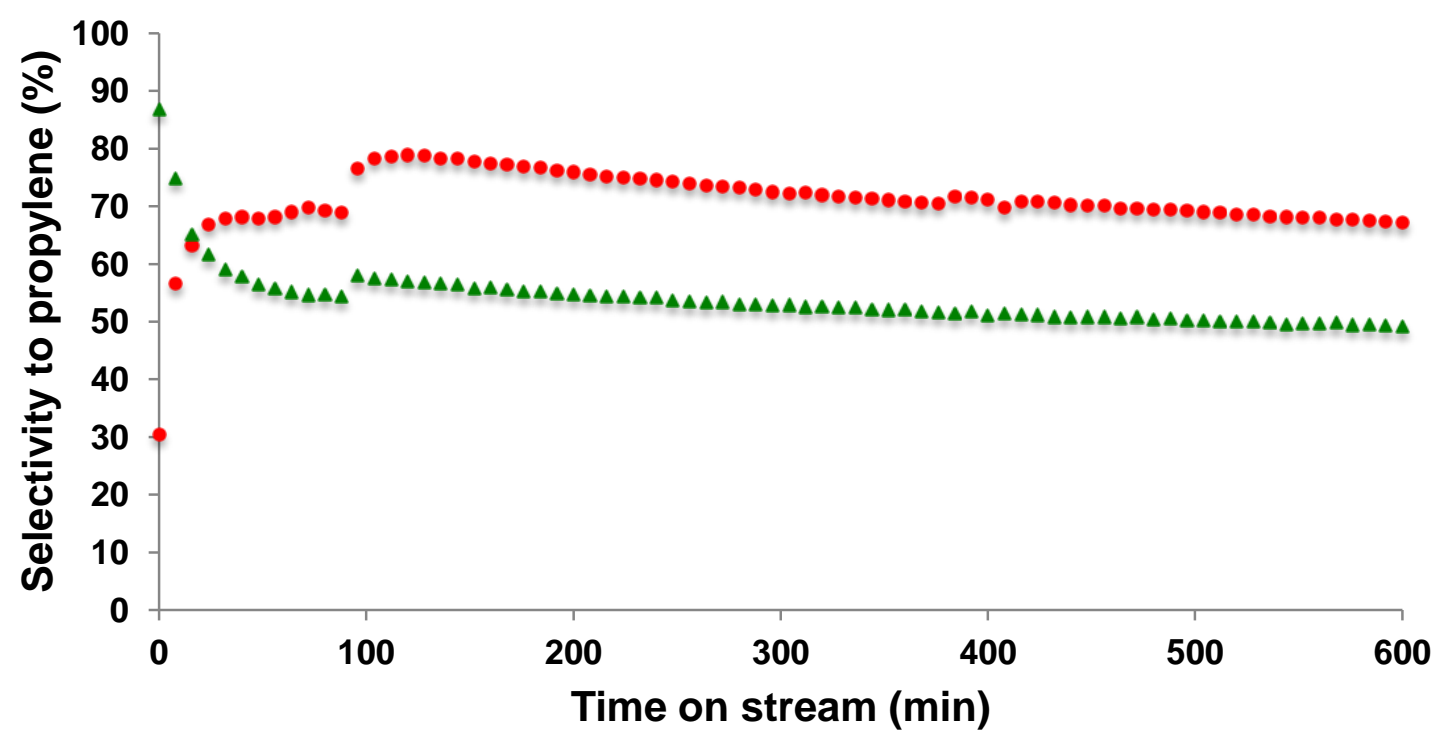

Figure 5. Dehydrogenation selectivity of $\mathrm{Zn}_{\mathrm{F}}$ (red) and $\mathrm{Zn}_{\mathrm{SEA}}$ (green) to propylene. The calculated TOF was calculated based on the total amount of $\mathrm{Zn}$ present in the catalyst.

The dehydrogenation reaction also produces ethylene, methane and butane, which are products of competing $\mathrm{C}-\mathrm{C}$ bond activation pathways. The $\mathrm{Zn} / \mathrm{SiO}_{2}$ catalyst dehydrogenation selectivity originates from the preference of these Lewis acidic centers for primarily activating $\mathrm{C}-\mathrm{H}$ bonds over $\mathrm{C}-\mathrm{C}$ bonds. ${ }^{4 a}$ The observed catalyst selectivity for $\mathrm{C}-\mathrm{H}$ bond activation is consistent with the greater propensity of $\mathrm{Zn}(\mathrm{II})$ propyl species to undergo $\beta$-hydrogen elimination over $\beta$-methyl elimination. The energy of activation for the former pathway $(\mathrm{C}-\mathrm{H}$ bond activation) is $\sim 10 \mathrm{kcal}$ lower than the energy barrier for the latter process $(\mathrm{C}-\mathrm{C}$ bond scission). ${ }^{4 a, 40}$ The activation of catalyst $\mathrm{Zn}_{\mathrm{F}}$ can proceed through protonation of the zinc-ethyl functionality by adjacent surface hydroxyls, producing ethane and a three-coordinate $\mathrm{Zn}$ (II) active site - the proposed active site in $\mathrm{Zn}_{\mathrm{SEA}}$.

Infrared Spectroscopy. Figure 9 shows the infrared spectra of the $\mathrm{Zn} / \mathrm{SiO}_{2}$ catalysts prepared by ALD and solution grafting methods. One-cycle $\mathrm{ZnO}$ deposition on $\mathrm{SiO}_{2}$ affords materials (e.g., $\mathrm{Zn}_{\mathrm{B}}$ ) that exhibit infrared spectral features identical to that of the silica substrate. ${ }^{41}$ The spectra of 
$\mathrm{SiO}_{2}$ and $\mathrm{Zn}_{\mathrm{B}}$ show strong, broad absorptions at $3700 \mathrm{~cm}^{-1}$ to $2900 \mathrm{~cm}^{-1}$ (Si-OH stretching), $1650 \mathrm{~cm}^{-1}\left(\mathrm{H}_{2} \mathrm{O}\right.$ adsorbed by siliceous materials), and $1250 \mathrm{~cm}^{-1}$ ( $\mathrm{Si}-\mathrm{O}$ bond stretching). The deposition of three and ten cycles of $\mathrm{ZnO}$ produces $\mathrm{Zn}_{\mathrm{C}}$ and $\mathrm{Zn}_{\mathrm{D}}$ (10 $\mathrm{ZnO}$ cycles; $0.75 \mathrm{~s}$ DEZ$0.75 \mathrm{~s}_{2} \mathrm{O}$ ) that exhibit shifted $\mathrm{Si}-\mathrm{O}$ absorption in the $1200 \mathrm{~cm}^{-1}$ region. $\mathrm{Zn}_{\mathrm{C}}, \mathrm{Zn}_{\mathrm{D}}$ and bulk $\mathrm{ZnO}$ exhibit weak O-H stretching bands $\left(3700 \mathrm{~cm}^{-1}\right.$ to $\left.2900 \mathrm{~cm}^{-1}\right),{ }^{42}$ potentially indicative of lower $\mathrm{O}-\mathrm{H}$ concentration. On the other hand, the spectrum of $\mathrm{Zn}_{\mathrm{Et}}$ (solution grafting) shows strong absorption at $2900 \mathrm{~cm}^{-1}$ which is attributable to $\mathrm{C}\left(\mathrm{sp}^{3}\right)-\mathrm{H}$ bond stretching, confirming the presence of zinc-bound ethyl functionality after the solution-phase grafting.

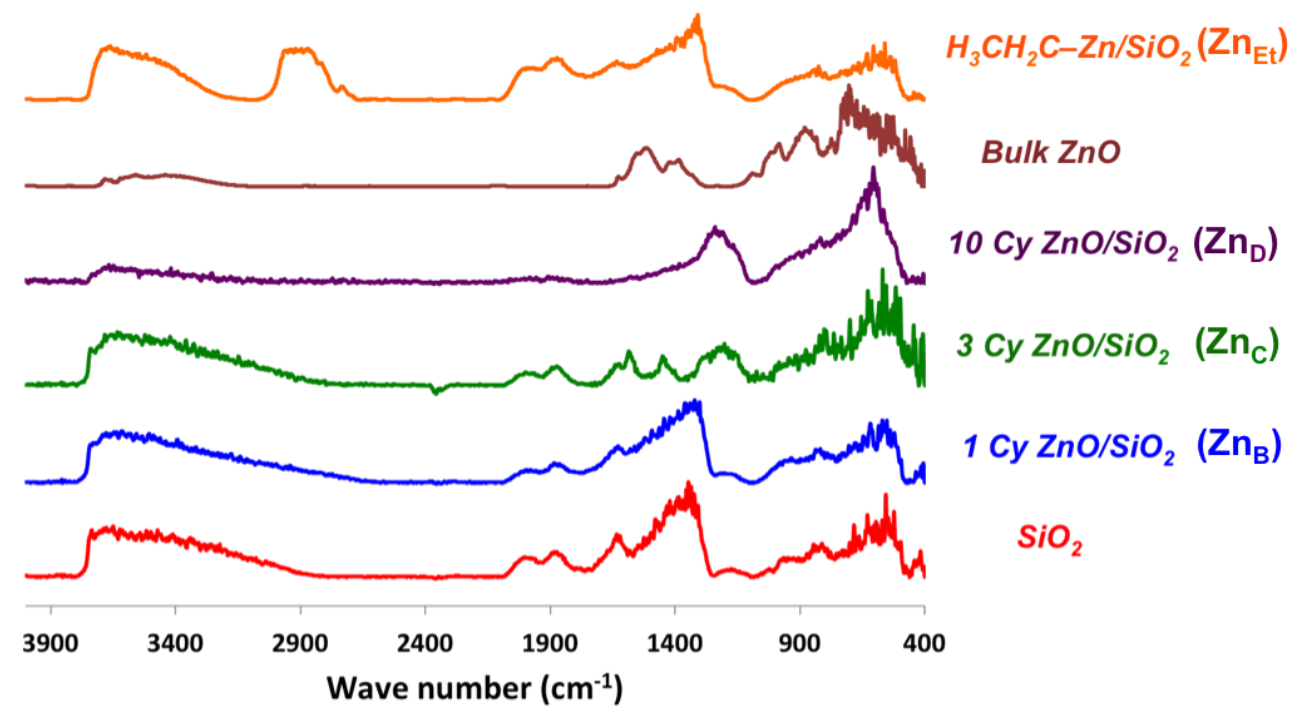

Figure 6. Infrared spectra of $\mathbf{S i O}_{\mathbf{2}}$ (red), $\mathbf{Z n}_{\mathbf{A}}$ (blue), $\mathbf{Z n}_{\mathbf{C}}$ (green), $\mathbf{Z n}_{\mathbf{D}}$ (purple), bulk $\mathbf{Z n O}$ (brown) and $\mathbf{Z n}_{\mathbf{E t}}$ (orange).

Multinuclear $\left({ }^{1} \mathrm{H},{ }^{13} \mathrm{C},{ }^{29} \mathrm{Si}\right)$ Solid-state MAS NMR Spectroscopy. Figure 10a shows the solidstate ${ }^{1} \mathrm{H}$ MAS NMR spectra of the $\mathrm{Zn}_{\mathrm{Et}}, \mathrm{Zn}_{\mathrm{B}}$ and non-metalated silica substrate. The upfield chemical shift at $0.31 \mathrm{ppm}$ for $\mathbf{Z} \mathbf{n}_{\mathbf{E t}}$ is indicative of zinc-bound methylene protons $\left(\mathrm{Zn}-\mathrm{CH}_{2}\right)$ based on reported solution-phase ${ }^{1} \mathrm{H}-\mathrm{NMR}$ spectral data for DEZ with the $\mathrm{Zn}-\mathrm{CH}_{2}-\mathrm{CH}_{3}$ chemical shift at $0.30 \mathrm{ppm} .{ }^{43}$ The $\mathrm{Zn}-\mathrm{CH}_{2}$ chemical shift overlaps with a broad signal ranging from 3 to -1 ppm, and with peak at $0.79 \mathrm{ppm}$. This broad peak could arise from the terminal methyl protons 
of $\mathrm{Zn}-\mathrm{CH}_{2}-\mathrm{CH}_{3}$, Si-OH, Si-OCH${ }_{2} \mathrm{CH}_{3}$ and $\mathrm{Si}-\mathrm{CH}_{2} \mathrm{CH}_{3}$ groups. ${ }^{44}$ The absence of $\mathrm{SiCH}_{2} \mathrm{CH}_{3}$ groups in $\mathrm{Zn}_{\mathrm{Et}}$ is further confirmed by direct-pulse ${ }^{29} \mathrm{Si}$ and cross-polarization ${ }^{1} \mathrm{H}_{-}{ }^{29} \mathrm{Si}$ MAS NMR experiments where only chemical shifts in the -100 to $-115 \mathrm{ppm}$ range, corresponding to tetrahedral Si centers typically observed in mesoporous silica materials, were observed (Figure 7b). ${ }^{13} \mathrm{C}$ MAS NMR experiments on $\mathrm{Zn}_{\mathrm{Et}}$ (Figure 7c) shows only two chemical shifts occuring at $0.7\left(\mathrm{Zn}-\mathrm{CH}_{2}\right)$ and $10 \mathrm{ppm}\left(\mathrm{ZnCH}_{2} \mathrm{CH}_{3}\right)$, confirming the presence of zinc-bound ethyl groups. The absence of downfield ${ }^{13} \mathrm{C}$ chemical shifts expected for silyl ethers and upfield signals for silanes (e.g., $\mathrm{SiCH} \mathrm{CH}_{3}$ ) is indicative of the absence of $\mathrm{Si}-\mathrm{O}-\mathrm{CH}_{2} \mathrm{CH}_{3}$ and $\mathrm{SiCH} \mathrm{CH}_{3}$ groups.

One-cycle DEZ deposition under surface-saturating conditions ( 0.75 Torr-s) followed by water treatment affords $\mathrm{Zn}_{\mathrm{B}}(10 \% \mathrm{Zn}, \mathrm{w} / \mathrm{w})$. $\mathrm{Zn}_{\mathrm{B}}$ shows a major proton chemical shift at 7 to 2 ppm (silica O-H functionalities, Fig. 7a). Interestingly, the broad chemical shifts from 0.8 to 0 ppm were observed at a lower intensity, indicating that the intense chemical shifts in the $\mathrm{Zn}_{\mathrm{Et}}$ spectrum could be mainly due to zinc-bound ethyl groups that can undergo protonolysis upon water treatment. Elemental analysis of $\mathbf{Z n}_{\mathbf{E t}}$ revealed $10.5 \% \mathrm{Zn}$ loading $(0.16 \mathrm{mmol})$ and 3.5 wt\% $\mathrm{C}(0.29 \mathrm{mmol})$. The corresponding molar composition translates to a $1.1: 1.0 \mathrm{Zn}$-to-ethyl group ratio. Under the assumption that no unreacted DEZ is present in $\mathrm{Zn}_{\mathrm{Et}}$, this ratio indicates that $91 \%$ of all $\mathrm{Zn}$ sites have metal-bound ethyl groups, while the remaining $9 \%$ underwent complete protonolysis of the two $\mathrm{Zn}-\mathrm{C}$ bonds to form $\mathrm{ZnO}$-type centers. 


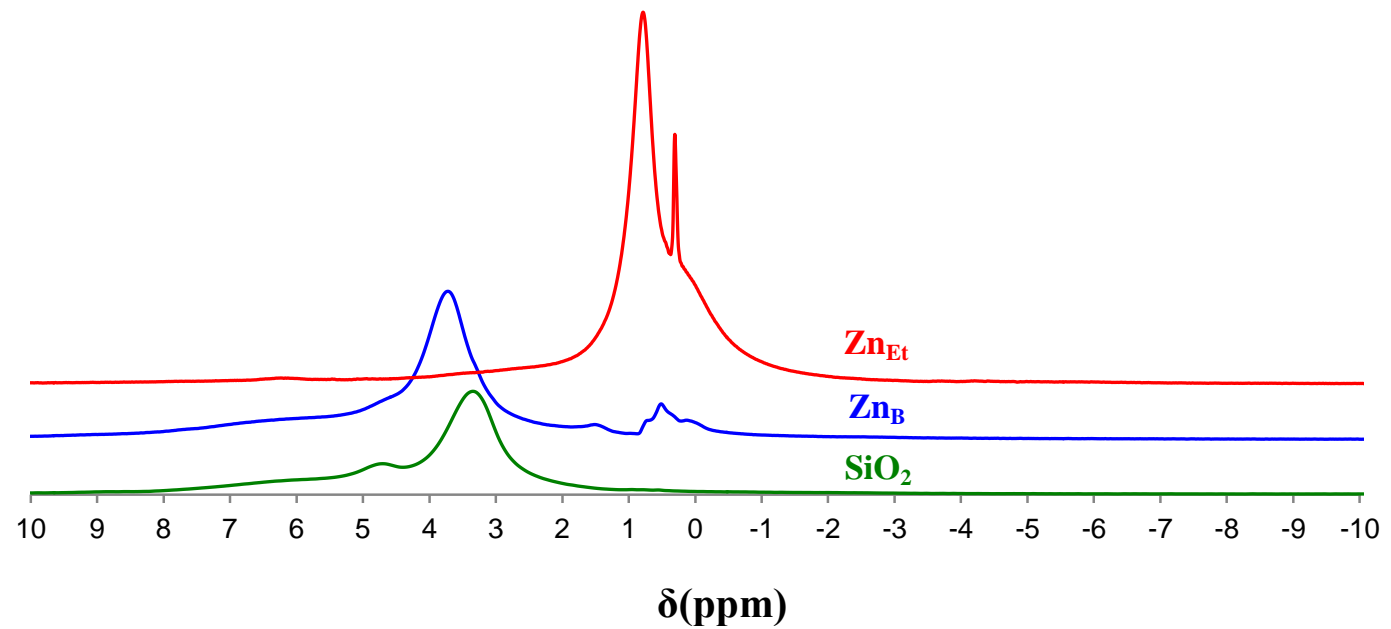

(a)

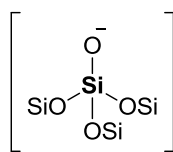

Q3

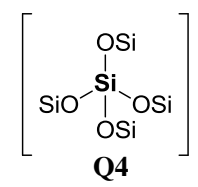

--- ${ }^{1} \mathrm{H} /{ }^{29} \mathrm{Si}$ Cross Polarization

$-{ }_{--}{ }^{29}$ Si Direct Pulse

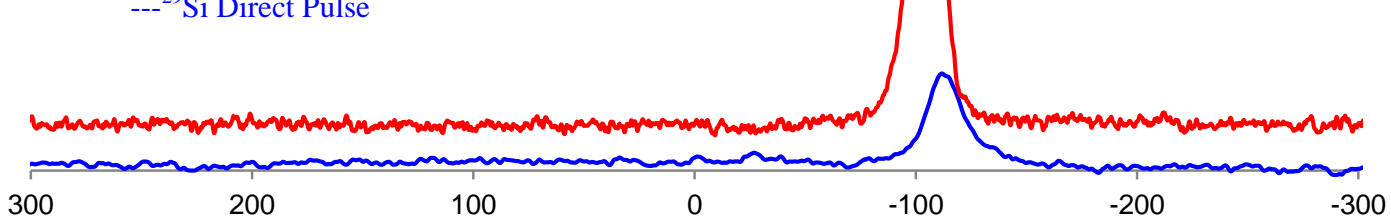

$\delta(p p m)$

$\mathrm{ZnCH}_{2} \boldsymbol{C H}_{3}(10 \mathrm{ppm})$

$\mathbf{Z n C H}_{\mathbf{2}} \mathbf{C H}_{\mathbf{3}}(0.7 \mathrm{ppm})$

(b)

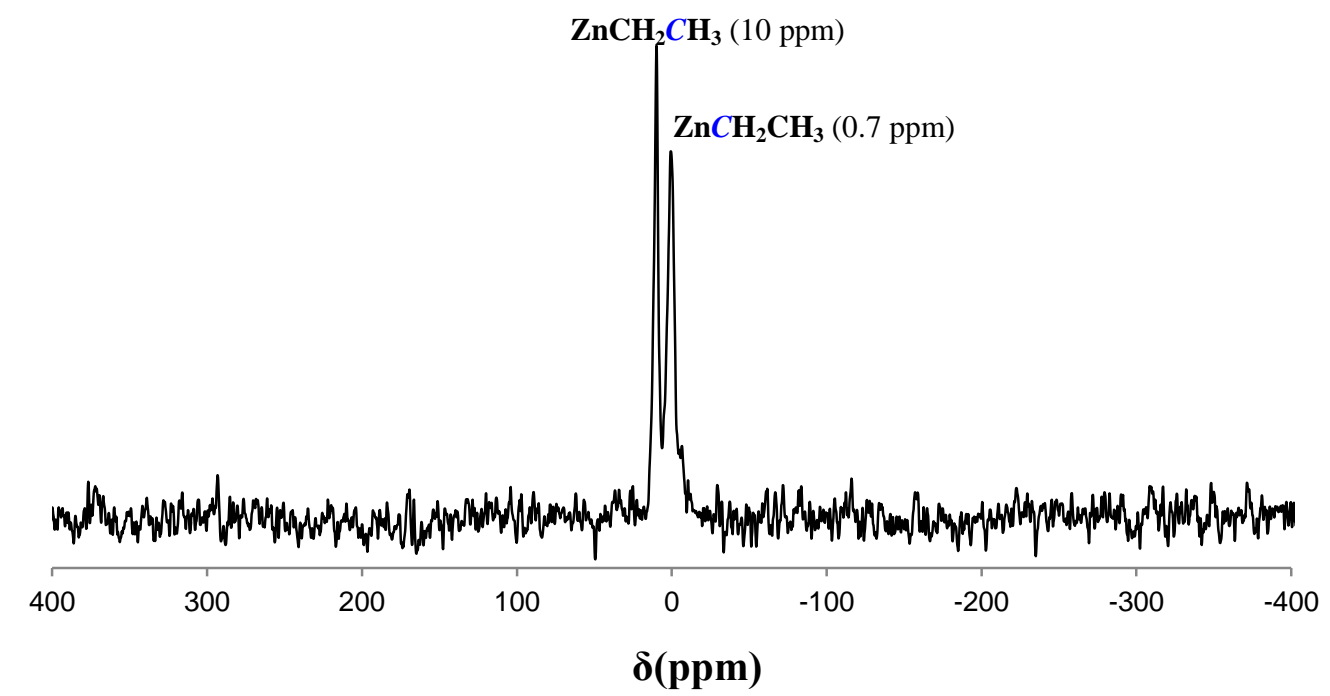

(c)

Figure 7. (a) Solid-state ${ }^{1} \mathrm{H}$ MAS NMR spectra of $\mathbf{Z} \mathbf{n}_{\mathbf{E t}}$ (green), $\mathbf{Z} \mathbf{n}_{\mathbf{B}}$ (red), and $\mathbf{S i O} \mathbf{2}_{\mathbf{2}}$ (blue); (b) ${ }^{29} \mathrm{Si}$ direct pulse and ${ }^{1} \mathrm{H} /{ }^{29} \mathrm{Si}$ cross polarization MAS NMR spectrum of $\mathrm{Zn}_{\mathrm{Et}}$; and $(\mathbf{c}){ }^{13} \mathrm{C}$ MAS NMR spectrum of $\mathrm{Zn}_{\mathrm{Et}}$. 


\section{X-ray Absorption Spectroscopy (XAS) and Powder X-ray Diffraction (PXRD). X-ray}

absorption spectroscopy (XAS) was employed to elucidate the zinc oxidation state and coordination environment in the $\mathrm{Zn} / \mathrm{SiO}_{2}$ systems. The X-ray absorption near edge spectra (XANES) and Extended X-ray Absorption Fine Structure (EXAFS) are considered separately. XANES is sensitive to both coordination number $(\mathrm{CN})$ and the electronegativities of the nearest neighbors around $\mathrm{Zn}(\mathrm{II})$ : absorption edge energies shift to higher energies with larger $\mathrm{CN}$, greater nearest neighbor electronegativity, and higher formal oxidation state of the absorbing atom, while post-edge features (EXAFS) provide an additional structural fingerprint. EXAFS provides information about the number of, and distance to, near neighbors of the scattering atom.

XAS characterization of $\mathrm{Zn}_{\mathrm{Et}}$ (DEZ solution grafting) and $\mathrm{Zn}_{\mathrm{B}}$ (one-cycle $\mathrm{ZnO}$ deposition) was carried out to elucidate the nature of the $\mathrm{Zn}$ sites generated from the two ALD half reactions: (1) DEZ grafting and (2) the subsequent $\mathrm{H}_{2} \mathrm{O}$ treatment step. The latter is discussed first. The XANES spectrum of $\mathrm{Zn}_{\mathrm{B}}$ closely resembles that of a single site $\mathrm{Zn}^{2+} / \mathrm{SiO}_{2}$ catalyst previously reported by our group $\left(\mathrm{Zn}_{\mathrm{SEA}}\right)$, suggesting similar coordination environments around $\mathrm{Zn}$ in both materials (Figure 8). The edge energies for these materials are $9.6644 \mathrm{keV}$ and $9.6646 \mathrm{keV}$ respectively, slightly greater than the $9.6637 \mathrm{keV}$ edge energy of the Würtzite $\mathrm{ZnO}$ standard and consistent with four-coordinate, divalent $\mathrm{Zn}$. However, the relative intensities of the first two absorption maxima above the edge in $\mathrm{Zn}_{\mathrm{SEA}}$ and $\mathrm{Zn}_{\mathrm{B}}$ differ from those of $\mathrm{ZnO}$, supporting the conclusion that the $\mathrm{Zn}$ in these samples is not located in Würtzite-structured domains. While precise assignment of XANES absorption features is in general not possible without high level electronic structure theory calculations, the absorption spectrum of $\mathrm{ZnO}$ roughly mirrors the conduction band density of states in this well-studied semiconductor, while the pair of absorption maxima for $\mathrm{Zn}_{\mathrm{SEA}}$ and $\mathrm{Zn}_{\mathrm{B}}$ can reasonably be assigned to $\mathrm{Zn} 4 \mathrm{p}$-derived 
states of $A_{1}\left(p_{z}\right)$ and $E\left(p_{x}, p_{y}\right)$ symmetry for single site $\mathrm{Zn}(\mathrm{OSi})_{2}(\mathrm{HOSi})_{2}$ centers of approximate $\mathrm{C}_{2 \mathrm{~V}}$ symmetry. ${ }^{4 \mathrm{a}}$

As in $\mathrm{ZnO}$, zinc in DEZ is also formally divalent. However, the lower electronegativity of carbon vs. oxygen and the two-coordinate linear geometry in DEZ give rise to significant differences between their XANES spectra. In particular, the edge energy of $9.6618 \mathrm{keV}$ is closer to that of $\mathrm{Zn}$ metal foil $(9.6608 \mathrm{keV})$ than to that of $\mathrm{ZnO}$. However, the maximum absorption in the DEZ spectrum at $9.6625 \mathrm{keV}$ makes DEZ readily distinguishable from Zn metal, which lacks this feature. In DEZ, the strong absorption at the XANES edge is a result of the allowed photoexcitation of a $\mathrm{Zn}$ 1s electron into the two unoccupied, nonbonding $\mathrm{Zn} 4 \mathrm{p}$ orbitals provided by the linear coordination geometry. The third $\mathrm{Zn} 4 \mathrm{p}$ orbital in DEZ is of $\sigma^{*}(\mathrm{Zn}-\mathrm{C})$ character and its energy is well above the ionization energy for the $\mathrm{Zn} 1$ s electron; the resulting short lifetime of this state gives rise to a broad, low intensity feature near $9.675 \mathrm{keV}$.

The value of the edge energy for $\mathrm{Zn}_{\mathrm{Et}}(9.6624 \mathrm{keV})$ is intermediate between that of $\mathrm{ZnO}$ (9.6637 keV) and DEZ (9.6618 keV), consistent with a bonding environment intermediate between these references. The first absorption maximum above the edge is of lower intensity than that of $\mathrm{DEZ}$ and more comparable to that of $\mathrm{ZnO}$, suggesting smaller contribution from nonbonding $\mathrm{Zn} 4 \mathrm{p}$ orbitals and therefore a coordination number greater than 2. This interpretation is supported by a fit to the EXAFS region of $\mathrm{Zn}_{\mathrm{Et}}$, which yields $\mathrm{CN} \approx 3$. While the edge energy of $9.6624 \mathrm{keV}$ is lower than that of $\mathrm{ZnO}$, it is greater than that of $\mathrm{DEZ}$ and remains consistent with $\mathrm{Zn}$ in the $2+$ oxidation state. (A more detailed investigation into the effects of coordination number, ligand electronegativity, and ligand-metal bond character in main group organometallic compounds has recently been completed by our group and will be reported separately.) 
Table 2. Summary of XAS data for $\mathrm{Zn} / \mathrm{SiO}_{2}$ species and reference compounds.

\begin{tabular}{|c|c|c|c|c|c|}
\hline Treatment & Edge Energy, keV & $\mathbf{N}_{\mathbf{Z n}-\mathbf{O} / \mathrm{C}}$ & $\mathbf{R}, \stackrel{\AA}{A}$ & $\Delta \sigma^{2}\left(\mathbf{x} 10^{3}\right)$ & E0, eV \\
\hline ZnO Standard & 9.6637 & 4.0 & 1.98 & 0.0 & -0.1 \\
\hline DEZ Standard & 9.6618 & 2.0 & 1.95 & 0.0 & 0.3 \\
\hline $\mathrm{H}_{3} \mathrm{CH}_{2} \mathrm{C}-\mathrm{Zn} / \mathrm{SiO}_{2}\left(\mathrm{Zn}_{\mathrm{Et}}\right)$ & 9.6624 & 2.9 & 1.95 & 5.9 & 1.1 \\
\hline $\mathrm{ZnO}(1 \mathrm{cy}) / \mathrm{SiO}_{2}\left(\mathrm{Zn}_{\mathrm{B}}\right)$ & 9.6644 & 3.9 & 1.97 & 2.3 & -2.0 \\
\hline $\begin{array}{l}\mathrm{Zn}\left(\mathrm{NH}_{3}\right)^{+2} / \mathrm{SiO}_{2} \\
\text { Calcined } 300^{\circ} \mathrm{C}\left(\mathrm{Zn}_{\text {SEA }}\right)\end{array}$ & 9.6646 & 3.8 & 1.98 & 2.5 & 0.2 \\
\hline
\end{tabular}

Figure 9 shows the extended X-ray absorption fine structure (EXAFS) spectra recorded for $\mathrm{Zn}_{\mathrm{Et}}$ and $\mathrm{Zn}_{\mathrm{B}}$, and the $\mathrm{Zn}(\mathrm{II})$ standards DEZ and $\mathrm{ZnO}$. DEZ is monomeric both in solution ${ }^{45}$ and in the solid phase, ${ }^{46}$ with the two-coordinate $\mathrm{Zn}$ center exhibiting an average $\mathrm{Zn}-\mathrm{C}$ bond distance of $1.95 \AA$. DEZ exhibits a relatively small first shell Zn-C scattering centered near $1.4 \AA$ (phase-uncorrected distance) and no meaningful higher shell scattering. Bulk zinc oxide, on the other hand, adopts the Würtzite structure with each four-coordinate $\mathrm{Zn}$ (II) center surrounded by four oxygen atoms in a nearly tetrahedral environment (average $\mathrm{Zn}-\mathrm{O}$ bond distance of 1.98 $\AA$ ). ${ }^{4 a, 47} \mathrm{ZnO}$ exhibits a more intense first shell scattering centered near $1.5 \AA$ (phase uncorrected distance). The observed greater intensity of the first shell scattering peak for $\mathrm{ZnO}$ compared to DEZ results from differences in (1) $\mathrm{Zn}$ coordination numbers $(\mathrm{ZnO}=4 ; \mathrm{DEZ}=2)$ and (2) intrinsic scattering amplitude of the zinc-bound atoms (O scattering > C scattering). 


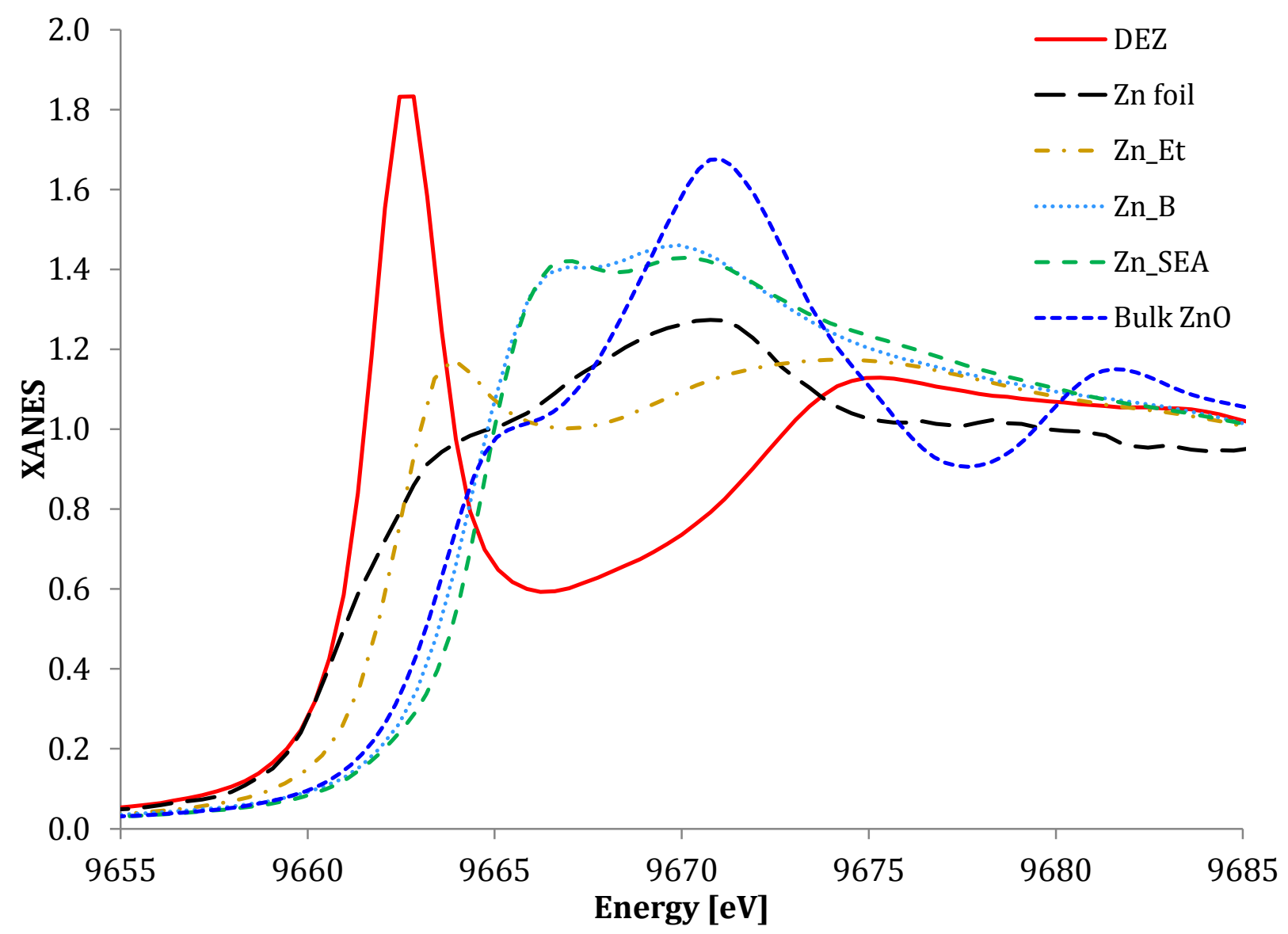

Figure 8. XANES spectra of DEZ, $\mathrm{Zn}$ foil, $\mathrm{Zn}_{\mathrm{Et}}, \mathrm{Zn}_{\mathrm{B}}$, and bulk $\mathrm{ZnO}$.

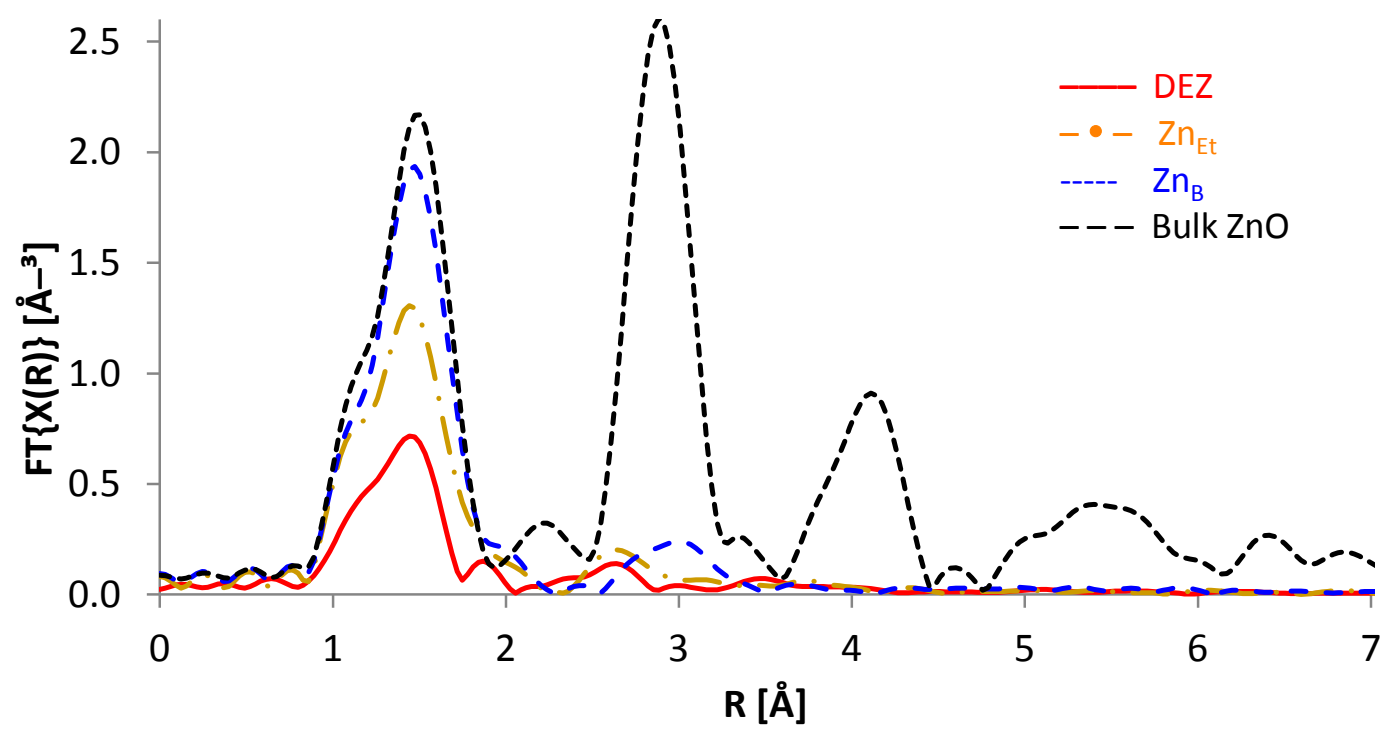

Figure 9. EXAFS spectra of DEZ, $\mathrm{Zn}_{\mathrm{Et}}, \mathrm{Zn}_{\mathrm{B}}$ and $\mathrm{ZnO}$. 
The first shell scattering peak intensity for $\mathrm{Zn}_{\mathrm{Et}}$ is consistent with tri-coordinate $\mathrm{Zn}$ (II) centers; each 16-electron $\mathrm{Zn}$ center is bound to two $\mathrm{O}$ atoms and one $\mathrm{C}$ atom (average bond distance of $1.95 \AA$ ). No significant higher shell scattering was observed for $\mathrm{Zn}_{\mathrm{Et}}$, confirming the uniformity of ethyl zinc(II) species on silica. $\mathrm{Zn}_{\mathrm{B}}$, on the other hand, exhibits first shell scattering with amplitude almost equal to that of $\mathrm{ZnO}$, consistent with the presence of 18-electron, fourcoordinate $\mathrm{Zn}(\mathrm{II})$ sites with a $1.97 \AA$ average $\mathrm{Zn}-\mathrm{O}$ bond distance. ${ }^{4 \mathrm{a}} \mathrm{Zn}_{\mathrm{B}}$ exhibits a very weak second-shell scattering peak and no significant higher shell scattering, indicative of isolated $\mathrm{ZnO}$ species. In addition, the XAS spectrum of $\mathrm{Zn}_{\mathrm{B}}$ resembles that of the single-site $\mathrm{Zn}$ (II) on silica catalyst that we reported earlier, prepared via strong electrostatic adsorption of $\left[\mathrm{Zn}\left(\mathrm{NH}_{3}\right)_{4}\right]^{2+}$ on silica followed by calcination $\left(\mathrm{Zn}_{\mathrm{SEA}}\right.$, Table 2$)$. The $\Delta \sigma^{2}$ values for $\mathrm{Zn}_{\mathrm{B}}$ and $\mathrm{Zn}_{\mathrm{SEA}}$ are somewhat greater than zero (i.e. somewhat greater than those of $\mathrm{ZnO}$ ), consistent with the greater diversity of $\mathrm{Zn}-\mathrm{O}-\mathrm{Si}$ geometries likely to exist on the surface of amorphous silica vs. the crystallographically well-defined $\mathrm{Zn}-\mathrm{O}-\mathrm{Zn}$ environment in $\mathrm{ZnO}$. The unusually large $\Delta \sigma^{2}$ value for $\mathrm{Zn}_{\mathrm{Et}}$ may also reflect differences between $\mathrm{Zn}-\mathrm{O}$ and $\mathrm{Zn}-\mathrm{C}$ bond lengths; however, attempts to fit $\mathrm{Zn}-\mathrm{O}$ and $\mathrm{Zn}-\mathrm{C}$ contributions separately in a single scattering shell lead to mathematically overspecificed fits with no unique solutions ${ }^{4 a}$ Furthermore, $\mathrm{ZnO}$ as isolated species in $\mathrm{Zn}_{\mathrm{B}}$ is also supported, albeit inconclusively, by the absence of higher nuclearity crystalline phases based on PXRD characterization (Figure S8 in the Supporting Information (SI)). The PXRD spectrum of $\mathrm{Zn}_{\mathrm{B}}$ resembles that of the amorphous $\mathrm{SiO}_{2}$ support. 


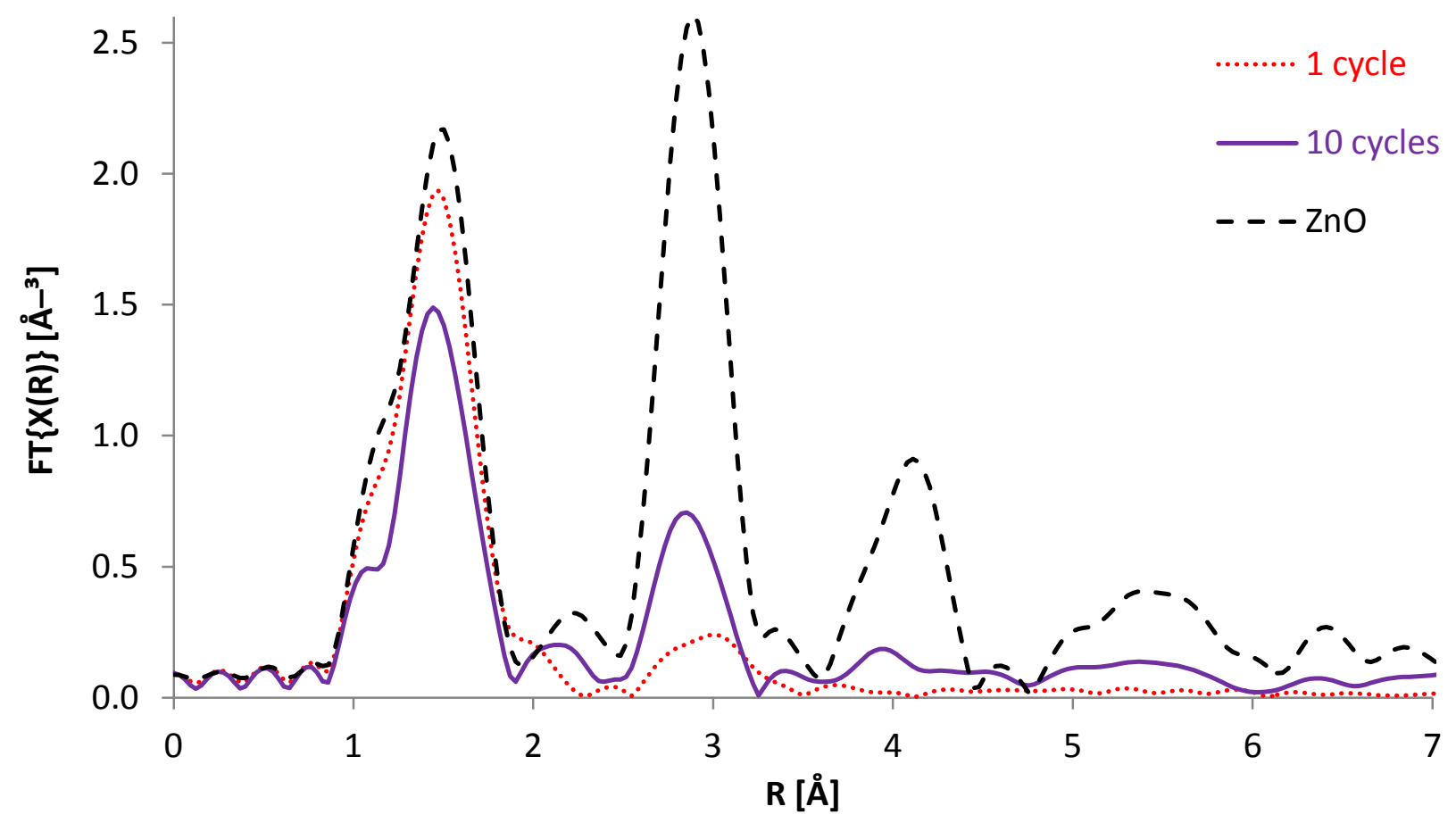

Figure 10. EXAFS spectra of bulk $\mathrm{ZnO}, \mathrm{Zn}_{\mathrm{B}}\left(1\right.$ cycle $\left.\mathrm{ZnO} / \mathrm{SiO}_{2}\right)$ and $\mathrm{Zn}_{\mathrm{D}}\left(10\right.$ cycles $\left.\mathrm{ZnO} / \mathrm{SiO}_{2}\right)$.

The EXAFS spectrum of $\mathrm{Zn}_{\mathrm{D}}$ (10-cycle deposition of $\mathrm{ZnO}$ ) features stronger scattering near 3.0 $\AA$ and hints of higher shell peaks near 4.0 A and $5.5 \AA$ (Figure 10). These higher shell scattering peaks are indicative of higher nuclearity $\mathrm{Zn}$ assemblies (e.g., clusters, particles) with structural features similar to bulk $\mathrm{ZnO} .^{47,48}$ Interestingly, the first shell scattering peak is much weaker in $\mathrm{Zn}_{\mathrm{D}}$, with an average coordination number of 2.7 and bond distance of $1.96 \AA$. The lower apparent $\mathrm{Zn}-\mathrm{O}$ coordination number is attributable to the presence of interstitial metallic zinc, also detected by PXRD analysis (Figure S7b in SI). PXRD analysis of $\mathrm{Zn}_{\mathrm{C}}\left(3 \mathrm{ZnO}\right.$ cycles/SiO$\left.{ }_{2}\right)$ and $\left.\mathrm{Zn}_{\mathrm{D}}(10 \mathrm{ZnO} \text { cycles/SiO})_{2}\right)$ revealed the presence of $\mathrm{Zn}(0)$ based on the peaks at $2 \theta=36.3^{\circ}$, $39.0^{\circ}, 43.2^{\circ}$ and $54.3^{\circ}$.

Mechanism of $\mathbf{Z n}-\mathrm{CH}_{2} \mathrm{CH}_{3}$ Activation. Since the active sites in catalysts $\mathrm{Zn}_{\mathrm{E}-\mathrm{G}}$ contain ethyl zinc functionalities, the transformations of the ethyl group can be unambiguously monitored, as the incoming substrate (propylene) and hydrogenation product (propane) are both $\mathrm{C}_{3^{-}}$ 
hydrocarbons. Gas chromatographic monitoring of the $\mathrm{C}_{2}$ (ethane and ethene) and $\mathrm{C}_{4}$ (butane) hydrocarbon generated under reaction conditions suggests multiple ethyl-zinc activation pathways. In order to understand the mechanisms of ethyl-zinc activation, Density Functional Theory (DFT) calculations were performed (Figure 11). Two contributing non-redox pathways are predicted for the observed rapid generation of ethane, which include (1) protonation of the zinc-bound ethyl groups (2-TS) by adjacent surface hydroxyls with an intrinsic energy barrier of $35.9 \mathrm{kcal} / \mathrm{mol}$, and (2) direct hydrogenolysis of the Zn-Et bond by molecular hydrogen (3-TS) with an intrinsic energy barrier of $57.5 \mathrm{kcal} / \mathrm{mol}$, suggesting that pathway 2 is relatively less favorable. The proposed ethane-generating zinc-ethyl activation pathways are considered productive organometallic transformations as they both generate $\mathrm{Zn}(\mathrm{II})$ species that are proposed key intermediates in the catalytic cycle. Protonation of the zinc-carbon bond by adjacent surface hydroxyls forms a three-coordinate $16 e^{-} \mathrm{Zn}$ (II) center (2) which is the same active site proposed to be responsible for propane dehydrogenation activity of $\mathrm{Zn}_{\text {SEA }} \cdot{ }^{4 \mathrm{a}} \mathrm{Zn}-\mathrm{Et}$ bond hydrogenolysis, on the other hand, generates ethane and a $16 e^{-} \mathrm{Zn}$ (II) hydride (3), which was proposed to be a key intermediate in the hydrogenation of propylene by $\mathrm{Zn}_{\text {SEA. }}{ }^{4 a}$ 

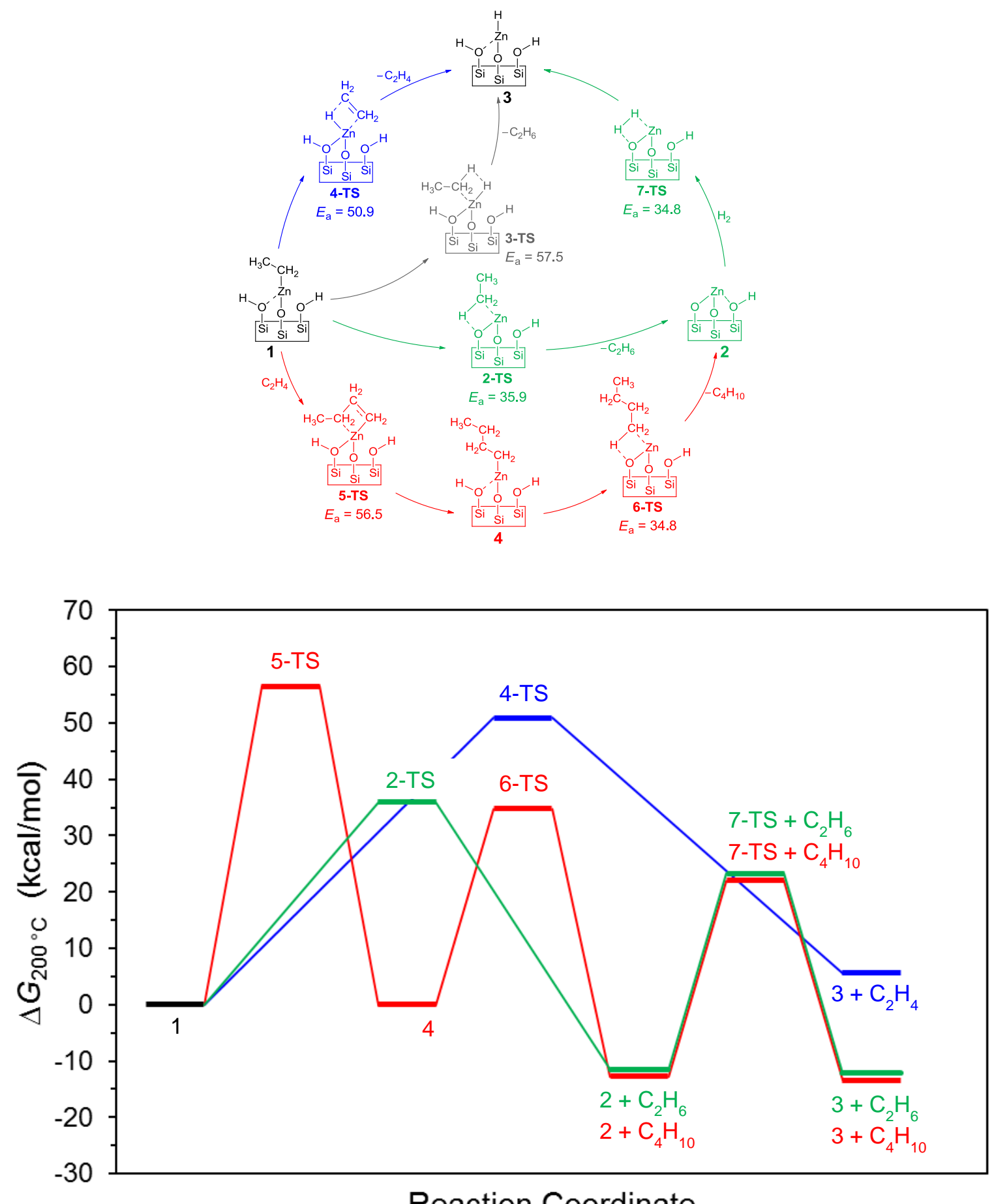

Figure 11. Different activation mechanisms of $\mathrm{Zn}-\mathrm{CH}_{2} \mathrm{CH}_{3}$ to form $\mathrm{C}_{2}$ and $\mathrm{C}_{4}$ hydrocarbons predicted by DFT calculations. The intrinsic activation energy $\left(E_{\mathrm{a}}, \mathrm{kcal} / \mathrm{mol}\right)$ associated with each step is shown.

The slower generation of ethylene under reaction conditions is consistent with the resistance of zinc alkyl species to $\beta$-hydrogen elimination (Figure 4; 4-TS, $E_{\mathrm{a}}=50.9 \mathrm{kcal} / \mathrm{mol}$ ). In 
addition to ethylene, this pathway also generates a three-coordinate $16 e^{-} \mathrm{Zn}$ (II) hydride (3). Butane formation, on the other hand, presumably proceeds via non-reductive route; ethylene generated in situ can insert into a $\mathrm{Zn}-\mathrm{CH}_{2} \mathrm{CH}_{3}$ group (Figure 14; 5-TS, $E_{\mathrm{a}}$ (calc) $=56.5$ $\mathrm{kcal} / \mathrm{mol}$ ), followed by protonation of the resulting zinc-bound butyl group. Activation of the catalyst $\mathrm{Zn}_{\mathrm{E}}$ generates ethane, ethylene and butane in a 13:2:1 ratio within the first 20 minutes of exposure to hydrogen and propylene at $200{ }^{\circ} \mathrm{C}$ (Figure 12). The observed selectivity to ethane, ethylene and butane is consistent with the calculated activation energies at $200{ }^{\circ} \mathrm{C}$ for the nonredox ethyl zinc activation pathways discussed above i.e., $E_{a 2 \text {-TS }}$ (alkyl protonation) $>E_{a 4-T S}$ (alkyl protonation) $>\mathrm{lc} E_{a 5-\mathrm{TS}}$ (ethylene insertion).

Alternatively, butane formation could proceed through homolytic activation of the ethylzinc groups, generating ethyl radicals than can eventually recombine to produce butane, and lower oxidation state zinc species such as metallic zinc. Interestingly, hydrogen activation of the ALD-synthesized catalysts with improved active site dispersion $\left(\mathrm{Zn}_{\mathrm{F}}\right.$ and $\left.\mathrm{Zn}_{\mathrm{G}}\right)$ gives ethane as the main activation product. This supports the hypothesis that higher ethyl zinc loading favors the formation of neighboring zinc alkyl sites that are prone to reductive decomposition and zinc agglomeration. 


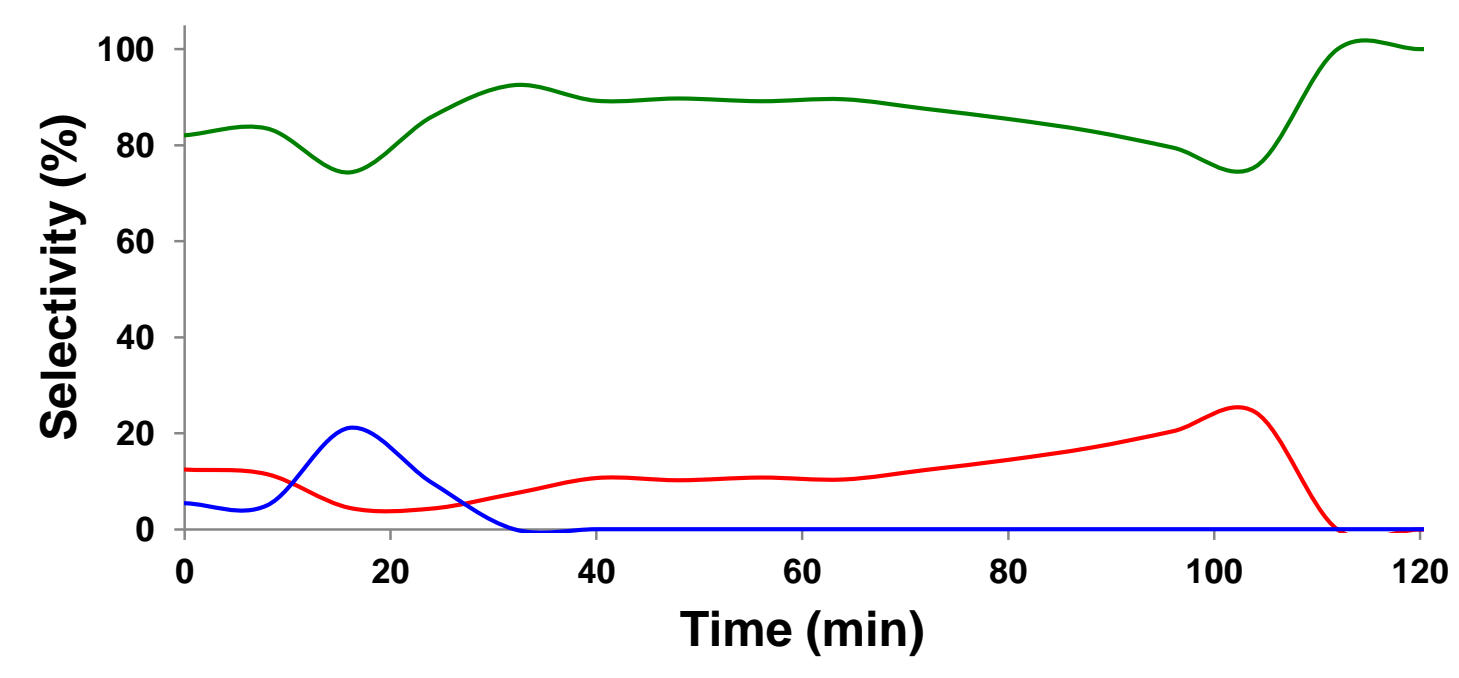

Figure 12. Plot of $\mathrm{H}_{3} \mathrm{CH}_{2} \mathrm{C}-\mathrm{Zn}$ activation selectivity to ethane (green), ethylene (red), butane (blue).

\section{Summary and Conclusions}

Controlled gas-phase grafting of zinc oxide and organo zinc active sites on high-surfacearea silica was achieved using an integrated atomic layer deposition-catalysis (I-ALD-CAT) tool. This approach has provided key insights into the mechanism of zinc grafting on silica supports at the monolayer level, and the reactivity and stability of these $\mathrm{Zn}$ sites as a function of dispersion. The I-ALD tool design allowed for the systematic reactivity comparison of different ALDgrafted zinc sites; in situ catalysis experiments confirmed much higher reactivity for the open shell 16-electron, tri-coordinate ethyl zinc-silica sites compared to 18-electron, tetra-coordinate zinc oxide-type centers. However, silica surface saturation with $\mathrm{Zn}(\mathrm{II})$ sites ( $75 \%$ of a monolayer) results in facile zinc agglomeration and catalyst deactivation under catalysis conditions. Improved active site dispersion was achieved through reduced DEZ dosing and substrate pretreatment (e.g., dehydration under vacuum), producing $\mathrm{Zn} / \mathrm{SiO}_{2}$ catalysts that are active and stable under propylene hydrogenation $\left(200^{\circ} \mathrm{C}\right)$ and propane dehydrogenation $\left(550^{\circ} \mathrm{C}\right)$ conditions. 


\section{Acknowledgements}

The work at Argonne National Laboratory was supported by the U.S. Department of Energy, Office of the Basic Energy Sciences, Chemical Sciences under contract DE-AC-02-06H11357. Use of the Advanced Photon Source is supported by the U.S. Department of Energy, Office of Science, and Office of the Basic Energy Sciences, under Contract DE-AC-02-06CH11357. MRCAT operations are supported by the Department of Energy and the MRCAT member institutions. High Resolution TEM images were obtained at UIC's Research Resources Center facility using the JEM-3010. The DFT calculations were performed using the computational resources available at the Argonne National Laboratory Center for Nanoscale Materials (CNM) and the computing resources provided on Fusion and Blues, high-performance computing clusters operated by the Laboratory Computing Resource Center at Argonne National Laboratory.

\section{References}

(1) Thomas, J.; Raja, R.; Lewis, D. Angew. Chem. Int. Ed. Engl. 2005, 44, 6456-6482.

(2) McKittrick, M.; Jones, C. J. Am. Chem. Soc. 2004, 126, 3052-3053.

(3) O’Neill, B.; Jackson, D.; Lee, J.; Canlas, C.; Stair, P.; Marshall, C. L.; Elam, J.; Kuech, T.; Dumesic, J.; Huber, G. W. ACS Catal. 2015, 5, 1804-1825.

(4) (a) Schweitzer, N.; Hu, B.; Das, U.; Kim, H.; Greeley, J.; Curtiss, L.; Stair, P.; Miller, J.; Hock, A. ACS Catal. 2014, 4, 1091-1098; (b) Hu, B.; Getsoian, A.; Schweitzer, N.; Das, U.; Kim, H.; Niklas, J.; Poluektov, O.; Curtiss, L.; Stair, P.; Miller, J.; Hock, A. J. Catal. 2015, 322, 24-37. (c) Dal Santo, V.; Guidotti, M.; Psaro, R.; Marchese, L.; Carniato, F.; Bisio, C. Proc. R. Soc. A - Math. Phys. 2012, 468, 1904-1926; (d) Vidal, V.; Theolier, A.; Thivollecazat, J.; Basset, J.; Corker, J. J. Am. Chem. Soc. 1996, 118, 4595-4602; (e) 
Basset, J.; Coperet, C,; Soulivong, D.; Taoufik, M.; Cazat, J. Acc. Chem. Res. 2010, 43, 323-334; (f) Dufaud, V.; Niccolai, G.; Thivollecazat, J.; Basset, J. J. Am. Chem. Soc. 1995, 117, 4288-4294; (g) Williams, L.; Guo, N.; Motta, A.; Delferro, M.; Fragala, I.; Miller, J.; Marks, T. Proc.Natl. Acad. Sci. USA 2013, 110, 413-418; (h) Ruddy, D.; Ohler, N.; Bell, A.; Tilley, T. J. Catal. 2006, 238, 277-285; (i) Coperet, C.; Chabanas, M.; Saint-Arroman, R.; Basset, J. Angew. Chem., Int. Ed. 2003, 42, 156-181; (j) Gajan, D.; Coperet, C. New J. Chem. 2011, 35, 2403-2408; (k) Coperet, C. Chem. Rev. 2010, 110, 656-680.

(5) Aaltonen, T.; Ritala, M.; Tung, Y.-L.; Chi, Y.; Arstila, K.; Meinander, K.; Leskelä, M. J. Mater. Res. 2004, 19, 3353-3358.

(6) Feng, H.; Lu, J.; Stair, P.; Elam, J. Catal Lett 2011, 141, 512-517.

(7) O’Neill, B.; Jackson, D.; Crisci, A.; Farberow, C.; Shi, F.; Alba-Rubio, A.; Lu, J.; Dietrich, P.; Gu, X.; Marshall, C.; Stair, P.; Elam, J.; Miller, J.; Ribeiro, F.; Voyles, P.; Greeley, J.; Mavrikakis, M.; Scott, S.; Kuech, T.; Dumesic, J.. Angew. Chem. Int. Ed. Engl. 2013, 52, 13808-13812.

(8) Lu, J.; Liu, B.; Greeley, J.; Feng, Z.; Libera, J.; Lei, Y.; Bedzyk, M.; Stair, P.; Elam, J. Chem. Mater. 2012, 24, 2047-2055.

(9) (a) Liang, X.; Li, J.; Yu, M.; McMurray, C.; Falconer, J.; Weimer, A. ACS Catal. 2011, 1, 1162-1165; (b) Lu, J.; Fu, B.; Kung, M. C.; Xiao, G.; Elam, J.; Kung, H.; Stair, P. C. Science 2012, 335, 1205-1208.

(10) George, S. Chem. Rev. 2010, 110, 111-131.

(11) Johnson, R.; Hultqvist, A.; Bent, S. Mater. Today 2014, 17, 236-246.

(12) Travis, C.; Adomaitis, R. Theor. Chem. Acc. 2013, 133, 1-11.

(13) (a) Feng, H.; Libera, J.; Stair, P.; Miller, J.; Elam, J. ACS Catal. 2011, 1, 665-673; (b) Anderson,V; Leick, N.; Clancey, J.; Hurst, K.; Jones, K.; Dillon, A.; George S. J. Phys. Chem. C 2014, 118, 8960-8970; (c) Goulas, A.; van Ommen, J. J. Mater. Chem. A, 2013, 1, 4647-4650, and references therein.

(14) (a) Aaltonen, T.; Ritala, M.; Sajavaara, T.; Keinonen, J.; Leskelä, M. Chem. Mater. 2003, 15, 1924-1928; (b) Feng, H.; Elam, J.; Libera, J.; Setthapun, W.; Stair, P. Chem. Mater. 2010, 22, 3133-3142.

(15) Christensen, S.; Elam, J. Chem. Mater. 2010, 22, 2517-2525.

(16) (a) Cao, K.; Zhu, Q.; Shan, B.; Chen, R. Nature, 2015, 5, 1-7; (b) Weber, M.; Mackus, A. ; Verheijen, M.; van der Marel, C.; Kessels, W. Chem. Mater. 2012, 24, 2973-2977. Sun, S.; Zhang, G.; Gauquelin, N.; Chen, N.; Zhou, J.; Yang, S.; Chen, W.; Meng, X.; Geng, D.; Banis, M. N.; Li, R.; Ye, S.; Knights, S.; Botton, G.; Sham, T.-K.; Sun, X. Nature, 2013, 3, 1-9.

(18) Camacho-Bunquin, J.; Shou, H.; Aich, P.; Beaulieu, D.; Klotzsch, H.; Bachman, H.; Marshall, C.; Hock, A.; Stair, P., Rev. Sci. Inst., 2015, 86, 084103.

(19) Zhuravlev, L. Langmuir 1987, 3, 316-318.

(20) Zhuravlev, L. Colloids Surf., A. 2000, 173, 1-38.

(21) Potapov, V.; Zhuravlev, L. Glass Phys. Chem. 2005, 31, 661-670.

(22) (a) Tynell, T.; Karppinen, M. Semicond. Sci. Technol. 2014, 29, 043001(1-15); (b) Lee, D.; Kim, S.; Noh, S. J. Nanosci. Nanotechnol. 2011, 11, 4312-4316; (c) Guziewicz, E.; Godlewski, M.; Krajewski, T.; Wachnicki, Ł.; Szczepanik, A.; Kopalko, K.; WójcikGłodowska, A.; Przeździecka, E.; Paszkowicz, W.; Łusakowska, E.; Kruszewski, P.; Huby, N.; Tallarida, G.; Ferrari, S. J. Appl. Phys. 2009, 105, 122413 (1-5); (d) Ku, C-H.; 
Huang, J-M.; Lin, C-M.; Lee, H-Y. Thin Solid Films 2009, 518, 1373-1376.

Becke, A. J. Chem. Phys. 1993, 98, 5648-5652.

(24) Frisch, M.; Trucks, G.; Schlegel, H.; Scuseria, G.; Robb, M.; Cheeseman, J.; Scalmani, G.; Barone, V.; Mennucci, B.; Petersson, G.; Nakatsuji, H.; Caricato, M.; Li, X.;

Hratchian, H.; Izmaylov, A.; Bloino, J.; Zheng, G.; Sonnenberg, J.; Hada, M.; Ehara, M.; Toyota, K.; Fukuda, R.; Hasegawa, J.; Ishida, M.; Nakajima, T.; Honda, Y.; Kitao, O.; Nakai, H.; Vreven, T.; Montgomery, J., Jr.; Peralta, J.; Ogliaro, F.; Bearpark, M.; Heyd, J.; Brothers, E.; Kudin, K.; Staroverov, V.; Kobayashi, R.; Normand, J.; Raghavachari, K.; Rendell, A.; Burant, J.; Iyengar, S.; Tomasi, J.; Cossi, M.; Rega, N.; Millam, N.; Klene, M.; Knox, J.; Cross, J.; Bakken, V.; Adamo, C.; Jaramillo, J.; Gomperts, R.; Stratmann, R.; Yazyev, O.; Austin, A.; Cammi, R.; Pomelli, C.; Ochterski, J.; Martin, R.; Morokuma, K.; Zakrzewski, V.; Voth, G.; Salvador, P.; Dannenberg, J.; Dapprich, S.; Daniels, A.; Farkas, Ö.; Foresman, J.; Ortiz, J.; Cioslowski, J.; Fox, D. Gaussian 09, Revision D.01; Gaussian Inc.: Wallingford, CT, 2009.

Hratchian, H.; Schlegel, H. J. Chem. Theory Comput. 2005, 1, 61-69.

Jiang, F.; Huang, J.; Niu, L.; Xiao, G. Catal Lett 2015, 145, 947-954.

Kucheyev, S.; Biener, J.; Wang, Y.; Baumann, T.; Wu, K.; van Buuren, T.; Hamza, A.; Satcher, J.; Elam, J.; Pellin, M. J. Appl. Phys. Lett. 2005, 86, 083108 (1-3). Wang, F.; Xiao, W.; Xiao, G. Catal Lett 2015, 145, 860-867.

(38) King, D.; Liang, X.; Li, P.; Weimer, A. Thin Solid Films, 2008, 516, 8517-8523.

(39) Berndt, H.; Lietz, G.; Lücke, B.; Völter, J. Appl. Catal. A.1996, 146, 351-363. Growth Des. 2012, 12, 5615-5620.

Dent, A.; Kokes, R. J. Phys. Chem. 1969, 73, 3772-3780.

Dent, A.; Kokes, R. J. Phys. Chem. 1969, 73, 3781-3790.

Dent, A.; Kokes, R. J. Phys. Chem. 1970, 74, 3653-3662.

Conner, W.; Innes, R.; Kokes, R. J. J. Am. Chem. Soc. 1968, 90, 6858-6858.

Dent, A..; Kokes, R. J. Am. Chem. Soc. 1969, 91, 7207-7208.

Vettel, S.; Vaupel, A.; Knochel, P. Tet. Lett. 1995, 36, 1023-1026.

Gao, Y.; Urabe, H.; Sato, F. J. Org. Chem. 1994, 59, 5521-5523.

(a) Zhao, Z.; Chiub, C.; Gong, J. Chem. Sci., 2015, 6, 4403-4425; (b) Li, F.; Yang, H.; Ju, T.; Li, X.; Hu, C. Int. J. Mol. Sci. 2012, 13, 9278-9297; (c) Perutz, R.; Sabo-Etienne, S. Angew. Chem. Int. Ed. Engl. 2007, 46, 2578-2592; (d) Heracleous, E.; Machli, M.; Lemonidou, A.; Vasalos, I.; J. Mol. Catal. A: Chem. 2005, 232 29-39

Rassy, E.; Pierre, A. J. Non-Cryst. Solids 2005, 351, 1603-1610.

Keyes, B.; Gedvilas, L.; Li, X.; Coutts, T. J. Cryst. Growth 2005, 281, 297-302.

Westerhausen, M.; Kneifel, A.; Kalisch, A. Angew. Chem. Int. Ed., 2005, 44, 96-98.

(a) Lesage, A. Phys. Chem. Chem. Phys., 2009, 11, 6876-6891; (b) Faulkner, R.;

DiVerdi, J.; Yang, Y.; Kobayashi, T.; Maciel, G. Materials 2013, 6, 18-46; (c) Tre 'bosc, J.; Wiench, J.; Huh, S.; Lin, V.; Pruski, M. J. Am. Chem. Soc. 2005, 127, 3057-3068; (d) Einholz, W.; Gollinger, W.; Haubold, W. Z. Naturforsch. B Chem. Sci. 1990, 45, 25-30 Eriksson, J.; Arvidsson, P. I.; Davidsson, Ö. Chem. Eur. J. 1999, 5, 2356-2361. Bacsa, J.; Hanke, F.; Hindley, S.; Odedra, R.; Darling, G. R.; Jones, A. C.; Steiner, A. Angew. Chem. Int. Ed. Engl. 2011, 50, 11685-11687.

Tohji, K.; Udagawa, Y.; Mizushima, T.; Ueno, A. J. Phys. Chem. 1985, 89, 5671-5676. 
(48) Lamberti, L. M. J. Phys. D: Appl. Phys. 2013, 46, 423001. 